\title{
Y Kuşağının Kariyer Algısı ve Gelecek Beklentisi: Kocaeli Organize Sanayi Bölgesi Örneği
}

\author{
Gözde MERT ${ }^{1}$ ve Serdar NESLİHANOĞLU²
}

$\ddot{O} z$

Y kuşağ1 nüfusu, Türkiye nüfusunun yaklaşık \%32'sidir ve çoğunlukla iş hayatındadır. Y kuşağ1, iş hayatında diğer kuşaklara göre farklı özellikler göstermektedir. Bu nedenle bu araştırma Y kuşağının iş hayatındaki kariyer algısı ve gelecek beklentisi konusuna odaklanmıştır. Bu amaçla, 2018 yılında, Kocaeli Organize Sanayi Bölgesi'nde çalışan, Y kuşağında bulunan bireylere, anket uygulanmıştır. Araştırmada, 271 kişinin verileri incelenmiştir. Araştırma sonucuna göre, Y kuşağı bireyleri hakkında ulaşılan bulgular şunlardır: motivasyon, teknoloji ve sosyalleşme, iş ortamı ve iş değiştirme boyutları cinsiyete bağlı olarak farklılaşmaktadır. Uyum, teknoloji ve sosyalleşme, ortam ve iş değiştirme boyutları eğitim düzeylerine bağlı olarak farklılaşmaktadır. İş ortamı boyutu, işyerindeki pozisyona bağlı olarak farklılaşmaktadır. Kariyer algısı ve gelecek beklentisi yaş, çalışma saati ve toplam iş tecrübesi boyutlarına göre farklılaşmamaktadır.

Anabtar Kelimeler: Y Kuşağı, Kariyer Algısı, Gelecek Beklentisi

Career Perception and Future Expectation of Generation Y: Kocaeli Organized Industrial Zone Case

\section{Abstract}

The population of Generation Y is approximately $32 \%$ of the population in Turkey, and they are mostly in business life. Generation Y shows different characteristics in business life compared to the other generations. Therefore, this research focuses on career perception and future expectation of Generation $\mathrm{Y}$ in business life. For this purpose, in 2018, a survey was conducted among the individuals in Generation Y in Kocaeli Organized Industrial Zone. 271 people participated in the research. According to the result of the research, the following was determined about the Generation Y: motivation, technology and socialization, work environment and changing job dimensions differ with respect to gender. Adaptation, technology and socialization, environment and changing job dimensions differ with respect to the level of education. The dimension of the business environment varies depending on the position at the workplace. The career perception and future expectation does not differ according to the age, working hours and total work experience dimension.

Key Words: Generation Y, Career Perception, Future Expectancy

\section{Atıf İçin / Please Cite As:}

Mert, G. ve Neslihanoğlu, S. (2020). Y kuşağının kariyer algısı ve gelecek beklentisi: Kocaeli organize sanayi bölgesi örneği. Manas Sosyal Araștırmalar Dergisi, 9(2), 927-945.

\footnotetext{
${ }^{1}$ Dr. Öğr. Üyesi - Nişantaşı Üniversitesi İktisadi, İdari ve Sosyal Bilimler Fakültesi, gozde.mert@nisantasi.edu.tr ORCID: 0000-0002-9314-0242

2 Dr. Öğr. Üyesi - Eskişehir Osmangazi Üniversitesi Fen-Edebiyat Fakültesi, sneslihanoglu@ogu.edu.tr ORCID: 0000-0001-8451-8023
} 


\section{Giriş}

Bilgi ve teknolojinin hızla gelişmesi ile birlikte günümüz bilgi çağı olarak tanımlanmaktadır. Örgütlerin en önemli sermayesi bilgi kaynağı olan insandır. Y kuşağını örgütte tutmak, örgüte sadakatini kazanmak ve örgüte çekmek için yöneticiler; Y kuşağının becerilerine yönelik mevcut yapıyı, uygulamaları ve kültürleri gözden geçirmelidirler.

Y Kuşağının iş dünyasında sayılarının artması ve kendine özgü özelliklere sahip olması bu bireyleri, diğer kuşaklardan ayırmaktadır. Y Kuşağı ile ilgili çalışmalar bu yönüyle ulusal ve uluslararası alanda birçok araştırmacının ilgisini de çekmektedir.

Bir lider yaratıp, onun etkisi altında çalışmak yerine daha rasyonel hareket etmek isteyen Y kuşağı için birlikte üretmek ve çalışmak önemlidir. Bu nedenle her bir kişinin ayrı ayrı çaba gösterdiği tek bir ekip olarak çalışabildikleri ortamlardan keyif almaktadırlar. Her bir ekip üyesi üretir ve yaratırken ortak bir amaca hizmet etme güdüsünde hareket ederler.

Günümüzde örgütlerin rekabet avantajı sağlamalarının nedenlerinden biri Y kuşağı bireyleridir. Kullanılan maddi kaynak, teknoloji ve elektronik sistemler örgüt başarısında rol oynamakla birlikte yetenekli Y kuşağı gücünün de önemi gün geçtikçe artmaktadır. Y kuşağında bulunan insan kaynağının artan önemi örgütlerin, yetenekli bireyleri örgüte çeken ve elde tutabilen, bireylerin yeteneklerini geliştiren, kariyer firsatları sunan, bireyleri geleceğe hazırlayan ve gelecekten beklentilerini olumlu yöne sevk eden politikalar benimsemesi gerekliliğini ortaya çıarmıştır.

$\mathrm{Bu}$ nedenlerden dolayı çalışmada, $\mathrm{Y}$ kuşağının kariyer algısı ve gelecek beklentisi ele alınmış ve iş hayatında çalışan Y kuşağı bireylerinin kariyer algıları ve gelecek beklentilerinin nasıl olduğu ve hangi değişkenlere göre farklılık gösterdiği saptanmaya çalışılmıştır. Geçerlilik ve güvenilirlik düzeyleri belirtildikten sonra, demografik değişkenler bazında kariyer algiları ve gelecek beklentileri boyutlarındaki farklılıklar araştırılmıştır. Bu amaç için bağımsız gruplar $\mathrm{t}$ testi ve tek yönlü ANOVA analizleri kullanılmıştır. Eğer ki farklılık gözlenmiş ise bu farklıllğın kaynağını bulmak için ise Scheffe testi ile çoklu karşılaştırmalar ve çıkarımlar yapılmıstır.

\section{Literatür İncelemesi}

\section{Kuşak Kavramı}

Kuşak konusunun tarihsel gelişimi ele alındığında bu konunun Antik Yunan ve Eski Misır’a kadar uzandığ1 görülür (Joshi, Dencker ve Franz, 2011). Bugüne kadarki gelişmeler, yaşamın değişik yönlerini etkilemiştir. Kültürel, toplumsal, politik, teknolojik, sosyal ve eğitsel sahada değişimler ortaya çıkmıştır (Mert, 2018, s. 707). Kuşak kavramını Türk Dil Kurumu; benzer yıllarda doğan, aynı çağ koşullarına sahip, yazg1ları, sıkıntıları ve ödevlerle yükümlülükleri olan bireyler topluluğu olarak ifade etmektedir (www.tdk.gov.tr). Kuşaklarla ilgili ilk kapsamlı sosyolojik araştırma 19. yüzyılın başlarında yapılmışıır. Daha yeni teoriler temel alınarak kuşaklar; paylaşılan ortak zaman, ortak yaşam şartları, zaman deneyimi ya da ortak bir yaşam öyküsü nedeniyle aynı zamandaki yaşıtlarına bağlı hisseden insan gruplarıdır (Broadbridge, Maxwell ve Ogden, 2007). Benzer bir tanım yapan Kupperschmidt'e (2000, s. 67) göre kuşak tanımı; sosyal, kamusal ve ekonomik unsurların etkisinde kalmış olan, birlikte aynı zaman dönemini yaşamış, aynı doğum yıllarını ve benzer deneyimlerini paylaşan insan grubudur (Mert, 2018, s. 709).

\section{Kuşak Kategorileri}

Birçok farklı alanda, kuşaklara yönelik ilgi, çok eski olmakla beraber, işletme alanında bu araştırmalar kısa bir geçmişe dayanmaktadır. Kuşaklar öncelikle tüketici davranışları yönünden ilgi çekmiştir. Yönetim alanında ilginin odağı, Y kuşağı ve 2000 kuşağının hangi özellikleriyle diğer kuşaklardan farklı olduğu ve işi ne yönde etkilediği hususudur (Macky, Gardner ve Forsthy, 2008, s. 857-861).

2000'li yıllarda; 1980 ve sonrasında doğan fertlerin çalışma hayatına girmesiyle, dünyada iş yaşantısı hızla değişmiştir. İş yaşantısına yeni katılanlar üzerinde yapılan ve farklılıkları ele alan, çok yayın olduğu görülmektedir. Twenge'nin (2010, s. 201) belirttiği gibi; The Wall Street Journal, Business Week ve Fortune dergisi, kuşak farkllıklarını ele alan yayınlar yapmıştır.

Yönetim alanında popüler yayınlara rağmen, akademik araştırmalar sınırlı sayıdadır. Yayınların akademik alan dışında yoğunlaşması, konunun dar çerçevede incelenmesine yol açmıştır. Gioncola (2006, s. 33) bu durumu, "kuşak yaklaşımının, bilimden çok popüler bir kültür olarak işlendiği" eleștirisi ile ifade etmiştir. ABD kuşak farklılıkları üzerine olan araştırmaların ise; 1980 ve 1990 yıllarını kapsadığı 
görülmektedir (Smith, 2000, s. 1-2; 43). Kuşak konusunu kurumsal olarak ele alan çalışmalar (Gusfield, 1957, s. 323-330) mevcuttur. Eski iş görenlerin yanında, 1980 sonra doğumlu kuşağın, iş gücü devir oranlarında ve iş değiştirmedeki artışı gibi bulguların, 2000 sonrası akademik araştırmaların, kuşak farkll1kkları konusuna yönelmelerine sebep olmuştur (Macky, Gardner ve Forsthy, 2008, s. 860; Smola ve Sutton, 2002, s. 363). Kuşak sınıflandırmasında, hangi kuşağın, hangi yılları içereceği konusunda fikir ayrılıkları mevcuttur (Reeves ve Oh, 2008, s. 296). Araştırmacılar, kuşakları sinıflandırma konusunda; kuşak farklılıklarının, farklı olayların bir sonucu olarak ortaya çıktığını ifade etmektedir (Mert, 2018, s. 709).

\section{Sessiz Kuşak}

Bu kuşak; gelenekçiler veya erişkin kuşak olarak da ifade edilmektedir. Sessiz kuşak, 1925-1945 yıllarında doğanları kapsamaktadır. Bu dönemdeki baskılar nedeniyle, bu nesil daha tedbirli davranışlar ortaya koymaktadırlar. Bu kuşak ayrıca, risk alma konusunda isteksizdir (Adıgüzel, Batur ve Ekşili, 2014, s. 171).Günümüzde, iş dünyasında sayıları azdır. Sessiz kuşak, bugünün iş dünyasının temellerini ortaya koyan kuşaktır. Büyük bilgi birikimine olmaları, pratik zekâları, onları kurumlar için kritik önemdeki fertler durumuna getirmiştir (Zemke, Raines ve Filipczak, 2013, s. 45-46).

\section{Baby Boomers Kuşağı}

Bu kuşağa; baby boomers (bebek patlaması) denilmesinin nedeni, bu dönem içinde ilaveten 17 milyon bebeğin doğmasıdır (O’Bannon, 2001). Bu kuşak, 1946 ile 1964 yılları arasında doğan kişileri ifade etmektedir. Amerika'da, nüfus büyüklüğu ile en çok etkiye sahip nesildir. Bu kuşağın doğduğu tarih aralıklarında dünyada Kennedy suikastı, Vietnam savaşı, cinsel devrim ve sivil ayaklanmalar gibi olaylar yaşanmıştır. Türkiye'de ise çok partili sisteme geçiş yaşanmışır. Bu dönemde, Cumhuriyet tarihinin ilk darbesi gerçekleşmiştir (Mert, 2018, s. 711). Refah, büyüme, mal ve hizmetler bu kuşak için önemlidir. Harcama ve eğlenmeye önem verirler. Batıda yetersiz üretim, "üret, sat" kavramını getirmiştir. Karşıt komünist blok ise; batı karşıtı politikalarını bu kuşak boyunca korumuştur. Doğu-Batı ikili dünya içinde doğan bir kuşaktır (Senbir, 2004, s. 23-24).

\section{Kuşağ1}

X Kuşağı, 1965-1979 yıllarında doğanlardır. Baby boomers kuşağının etkisinde oldukları için onların özelliklerini yansitırlar. X Kuşağı; Coupland (1991) "Generation X: Tales for an Accelerated Culture" kitabından sonra yaygın olarak kullanılmıştır. X Kuşağı aile, finans ve toplum konularında, güvensiz çevrede yetişmiştir. Ailelerinin işten atılmasına ve Amerikan global gücünün azalmasına tanık olmuştur. Durağan iç pazar, örgütlerin küçülmesi ve sınırlı iş gücü ortamında büyümüşlerdir. Anne-babalarından daha az geliri olan, ilk nesildir. Ebeveynlerin çalıştı̆̆ veya tek ebeveyn ile yaşayan bu nesil, kilitli kapiların ardında kendilerini koruyan çocuklar olmuşlardır (Demirkaya, Akdemir, Karaman ve Atan, 2015, s. 189).

$\mathrm{X}$ Kuşağının yalnız kalarak yetişmeleri ve hem babalarının hem de annelerinin sürekli işte bulunmaları işe bakış açılarını kendi anne babalarından daha farklı oluşmasına yol açmıştır. X kuşağına göre iş sadece mücadele yeri değildir, eğlence de içermelidir. X kuşağı, odaklandığı ve motive edildiği takdirde son derece iyi çalısısılar (Martin ve Tulgan, 2002, s. 30).

\section{Y Kuşağ1}

Y kuşağı, 1980-2000 aralığında doğan bireylerden oluşan bir nesildir. Bu kuşağa; "internet kuşağı”, "Millenial", "Echo-Boomers" ve "Nexters"da denilmektedir. Bu tanımlamalar, Y kuşağının önceki kuşaklar ile olan farkını belirlemek için kullanılmaktadır (Broadbridge, Maxwell ve Ogden, 2007, s. 523544).

Y kuşağı ve X kuşağı arasındaki en önemli fark, teknoloji, tüketim ve gönüllü ilişki içinde olmalarıdır. Y kuşağı bireyleri; sabırsız, girişimci, sonuca odaklanan, bireyci, özgüveni ve her şeyi isteyen ve tüketen, egosu yüksek ve bir bedel ödemeyi istemeyen, bürokrasi ve ciddiyetten hiç hoşlanmayan ve hız tutkunu olan bir nesildir (Altuntuğ, 2012, s. 206).

Y kuşağ1 üyeleri (Mert, 2018, s. 713):

- İşleri ile kendilerini ifade eder,

- Her şeyi anlamaya çalışır,

- Birçok işi bir anda yürütür, 
- Karar sürecinde aktif rol alarak, iş doyumu yaşar.

Y kuşağı üyeleri aşağıdaki özellikleri çalışma yaşamlarında ararlar (Mert, 2018, s. 713):

- Sorumluluk alma,

- Sayginlık,

• İş ortamında esneklik,

- Ekip çalışması,

- Sürekli öğrenmek,

- Her şeyi geçici olarak düşünmek,

- Beklentilerini anında yapma,

- İş yerinde, eğlence ve tutku beklentisi,

• İş ve özel yaşantı arasında denge.

\section{Z Kuşağ1}

Z kuşağı 2000 yılı ve sonrasında doğanlardır. Bu nesil, internet ve teknoloji içinde doğmuştur. Z Kuşağ1 (Mengi, 2012):

- Bireyselliğe önem veren,

- En yeni iletişim araçlarını kullanan,

- Yeniliğe açık,

- Sosyal medyayı haberleşmede kullanan,

- Arkadaşlık ilişkilerini Facebook ile yürüten,

- Teknolojiyi, bir yaşantı standardı olarak gören bir kuşaktır.

Bu kuşağın bilinen diğer karakteristik özellikleri ise; özgüvenleri oldukça yüksek, esnek ve kişisel özgürlüklerine düşkündürler. Mahremiyete çok önem vermektedirler. Arkadaşlarıyla buluşmaya ve onlarla ilişki geliştirmeye inanmamaktadırlar. Takım çalışmasına uygun olmayan hatta kendine dönük bir kuşaktır (Akdeniz, 2012; Kılıç, 2012).

\section{Kuşağ1}

M Kuşağı, 1995-2003 yılları arasında doğan kuşaktır. Teknoloji hayatlarının ayrılmaz bir parçasıdır. Bir tüketici olarak, almak istediği hizmeti veya ürünü internetten araştırıp, kıyaslama yaparlar. Yenilikleri takip eden, yetenekli ama içine kapanık bir kuşak olarak yetişmektedirler (Yelkikalan, Akatay ve Altın, 2010, s. 501-502). Bu kuşak üyelerinin kendilerine güvenen, özgürlüklerine oldukça önem gösteren, teknoloji tutkunu ve bireysel yaklaşım özelliklerine sahip oldukları ifade edilmektedir (Mert, 2018, s. 715).

\section{R Kuşağ1}

İş dünyasındaki değişimler, 2008 ekonomik krizi ile "recession generation" denen yeni bir kuşak tanımlamasını ortaya çıkarmışır. Bu yeni neslin profili, yüksek sorumluluk ve hızlı kariyer gelişimine sahip ve performansı öne çıkaran işgücü olarak tanımlanmaktadır (RANDSTAD, 2010).

\section{Kuşağ}

C Kuşağı, X veya Y kuşağı gibi yaş veya demografik kıstaslardan ayrı olarak daha çok inandıkları, ilgileri, yaklaşımları, değerler ve yaşam biçimleri ile ayrışan ve birbirine bağlı, dijital iletişimi yaşam döngüsü ile bütünleşmiş, teknolojiye hâkim bir kitle olarak tanımlanmaktadır (İçil, 2016). Bu kuşağın ismini oluşturan "C" harfi ilk olarak "connected" (bağli) kelimesini temsil ederken, daha sonraları bu harf "content" (içerik), "communicating" (iletişim kuran), "creativity" (yaratıcıllk), "control" (kontrol), "celebrity" (ünlü), "computerized" (bilgisayarli) ve "clicking" (tıklayan) gibi kelimeleri de kapsayan bir anlam oluşturmuştur (Ercan, 2012; Hardey, 2011, s. 749). Yani bu kuşak, bir yaş grubunu değil, düşünce ve davranış tarzını ifade etmektedir (Mert, 2018, s. 715-716). 


\section{Y Kuşağının Kariyer Algısı ve Gelecek Beklentisi}

Y kuşağını pozitif ve negatif özellikler olmak üzere genel olarak 12 özellikte anlatan Chester’a (2002) göre, Y kuşağ1; uyumlu, yenilikçi, yetenekli, esnek, hoşgörülü ve kararlı olmak gibi pozitif ve açık sözlü, sabırsız, duyarsız, serbest, şüpheci, saygısız, kendine aşırı güven gibi negatif özelliklere sahiptir.

Genel olarak Y kuşağı üyeleri; bireysel, gerçekçi, iyimser, ileri düşünceli, aynı anda birden çok görev yapabilen, teknoloji meraklısı, aynı zamanda sosyal, şehir yaşamına uyum sağlayabilen, çeşitliliğe açık, aktif, başarılı, işbirlikçi, ekip odaklı ama bireyci, açık fikirli, amaç yönlü, karamsar, sabırsız, özgürlüğüne düşkün, girişimci, yenilikleri kolay benimseyen, bağımsız, cesur ve yüksek özgüvene sahip olmak gibi karakteristik özelliklere sahiptirler (Glass, 2007, s. 100; Meier ve Crocker, 2010, s. 69; Yüksekbilgili, 2013, s. 346).

Y kuşağının işteki davranış ve beklentisi, diğer kuşaklardan farklılık göstermektedir. Özgürlüğe son derece düşkündürler. Teknolojiden vazgeçmezler ve teknolojiyi işlerine katmak isterler. Bu kuşak için sosyallik önemli olup, iş hayatının bunun önüne geçmesine izin vermezler (Keleş, 2011, s. 132).

\section{Y Kuşağının Kariyer Algısı}

Y kuşağ1 kariyer beklentisi yüksektir. Çabuk öğrenip, çabuk gelişim gösterirler. Kısa sürede yönetici olmayı istemektedirler. Y kuşağının yöneticilerine, büyük sorumluluklar yüklenmiştir. Beklentileri karşılanmadığ zaman Y kuşağ1, hızla iş değiştirme kararı verir. Y kuşağ1 iyi yönetilemezse; bu örgütü olumsuz etkiler. Y kuşağ1, kişiselleştirme ve özelleştirme yoluyla yönetilmelidir. Koçluk ve mentörlük, Y kuşağı için önemlidir (Baltaş, 2010, s. 29). Daha rekabetçi bir yaşam içinde olan Y kuşağının özellikleri aşağıdadır (Çoban, 2006, s. 220):

- Finans, danışmanlık ve bilişim alanını tercih etmektedirler.

- Elektronik ortamlarda iş ararlar. verirler.

- Çalışacakları yerin; kimliği, uluslararası olması, kariyer ve eğitim imkanlarının olmasına önem

- 4-6 ay arasinda iş bulmayı isterler.

- Bu kuşağı́n \%58’i iş bulma endişesi yaşar.

- Krizler karşısında geleceğe olumlu bakarlar.

• İş hayatında 4-6 yl içinde yönetici olacaklarını düşünürler.

- Girişimcilik yönleri çok yüksek olduğundan kendi işini yapmak isteyenlerin oranı \%45 üzerindedir.

Haftada 40 saatten fazla çalşsmayı uygun bulmaktadırlar. 9:00-17:00 saatleri arasında çalışmanın zorunlu olmasının değişmesi için çaba sarf ederler. İş yerindeki zamanlarını kendilerinin belirlemesine izin verilmesini isterler. Bu kuşak esnek bir yaklaşıma önem vermektedir. İşin ofiste veya başka yerde yapılmış olmasının önemsiz olduğunu savunurlar (Zemke, Raines ve Filipczak, 2013, s. 138-139).

Y kuşağını işte tutabilmek için aşağıdaki bazı hususların yapılması gerekmektedir (Akdemir vd., 2013: 19-20):

- Öğrenme ve bilgi paylaşımını kurum kültüründe öne çıkarmak.

- Ebeveynleri işgücü stratejisine katmak.

- Eğlenceli ve esnek bir iş yeri yaratmak.

- İşe odaklanmaya önem vermek.

- Genel yap1 ve sinırları belirlemek.

- İlk amirleri ile ilişkinin çok önem taşıdığını bilmek.

- Baby Boomers ve X kuşağının bilgisinden yararlanmak.

- Kişisel unsurları kullanmak.

- Y okur-yazarı olmak. 
Y kuşağ1 kariyerinde verimli olmak için fikirlerini özgürce ifade edebileceği ortamlarda çalışmak istemektedir. Kariyerlerinin ilerlemesini sosyal hayatlarına engel olarak görmemekte, esnek iş saatleri, üstleri ile dostça ilişkiler kurabilmekte ve kararlara ortak katılım gösterme isteğinde olmaktadırlar. Sıkı denetim ortamında olmadan, iş tanımlarının açıkça belirlenmiş olmasını beklemektedirler.

Kariyer gelişimi için tecrübenin gerekli olmadığını, kısa süre içinde başarı gösterildiği taktirde terfi edilmeyi istemektedirler. Lider veya yöneticilerinden yaptıklanı işle ilgili geri bildirim beklemekte, kariyer gelişimine yardımcı olması gerektiğini düşünmektedirler. Yaptıkları işin takdir edilmesi, eğitim firsatlarının engellenmemesi, internet erişimlerinin kısıtlanmaması, dış görünüşle ilgili katı kuralların olmaması motivasyon ve verimliliklerini de olumlu etkilemektedir.

Y kuşağ1, kariyer gelişimi için kendi işini kurmak istemektedir. Bu kuşak mevcut kuralların yerine; yetenek ve yaratıc1lklarını öne çıkaracakları ve fikirlerini değerlendirecekleri işletmeleri kurmak isterler (Mert, 2018, s. 723).

\section{Y Kuşağının Gelecek Beklentisi}

Y kuşağ1 kişileri, her şeyi kazanacaklarına ve dönüşümcü bireyler olduklarına inanmaktadırlar. Ebeveynlerinden farkli; modern teknoloji ve tüketime yönelik bir çevrede yetişmişlerdir (Aminul, Cheong, Yusuf ve Desa, 2011, s. 1803).

Y kuşağı çalışma hayatında, X kuşağından daha idealist olmakta, fakat baby boomers kuşağından daha gerçekçi bulunmaktadır. Buna ek olarak, Y kuşağı bireyleri daha iyimser ve gönüllülüğe daha yatkın bir nesildir.

Y kuşağının, ebeveynlerinin büyük bir kısmı boşanmış olan, okullarda daha fazla zaman harcayan, daha iyi bir eğitim alabilmek için ailesinin bulunduğu şehirlerden daha farklı bir yere giden ya da her iki ebeveyn de çalıştı̆ı için evde tek başına kalan bireylerdir. Bu gibi nedenlerle önceki kuşaklara göre daha küçük yaşlarda kendi kararlarını vermek ve birtakım işlerini kendileri yapmak zorunda kalmışlardır. Y kuşağı ne istediği ve istediğini elde etmek için gereksinim duyduğu unsurları belirleme konusunda önceki kuşaklara göre daha yeteneklidirler (Sheahan, 2006, s. 7).

Y kuşağının beklentileri diğer kuşaklara göre farklılık göstermektedir. Y kuşağı; yaptığ1 bir işi, hayatındaki beklentilerini karşılamadığında yeni bir iş aramayı bencillik olarak değil gerçekçilik olarak görmektedir (Yüksekbilgili, 2013, s. 346). Y kuşağ1 bireyleri, yaptıkları faaliyetlerde başarılı olmaları için onları destekleyen ebeveynler ve öğretmenler ile büyümüş olduklarından dolayı gelecekleri ile ilgili kararları da verirken ebeveynlerine danışmaya ya da güvendikleri daha deneyimli, bilgili rol modellerin tavsiyelerine ihtiyaç duymaktadır (Coggshall ve Coggshall, 2010). Ayrıca, faaliyetlerinin dünyada olumlu bir değişime katkı sağladığını görmesi de onlar için oldukça önemlidir. Y kuşağı gelecek beklentilerinin daha pozitif, yenilikçi fikirler üreten, süreçlere veya faaliyetlere katkı sağlayan ve bunun takdir edilmesini isteyen bir nesli temsil etmektedir.

\section{Yöntem}

$\mathrm{Bu}$ araştırmada Y kuşağındaki Kocaeli Organize Sanayi Bölgesinde çalsşan kişilerden elde edilen veriler esas alınarak analizler yapılmıştır. Verileri analizinde; ölçek ifadelerinin güvenilirlik analizi, açılayıcı faktör analizleri ve sonrasında farklılık analizleri ile hipotezler test edilmiştir. Verilerin analizlerinde SPSS 25 paket programı kullanılmıştır.

\section{Araştırma Amacı ve Hipotezler}

$\mathrm{Bu}$ araştırmanın amacı Kocaeli Organize Sanayi Bölgesinde çalışan ve aynı zamanda Y kuşağında yer alan katılımcıların kariyer algisının ve gelecek beklentilerinin farkında olunması ve sistemlerin de buna göre iyileştirilmesidir. Bu amaç doğrultusunda katılımcıların kariyer algısının tespiti faktör analizi ile motivasyon, uyum ve plan boyutuna indirgenirken; gelecek beklentisi hakkındaki düşünceleri ise aynı şekilde faktör analizi ile teknoloji ve sosyalleşme, ortam, ilişkiler ve iş değiştirme boyutuna indirgenmiştir. Katılımcıların kariyer algısı ve gelecek beklentisi bakımından sırayla cinsiyet, yaş, eğitim düzey, işyerindeki pozisyon, iş yerindeki çalışma saati ve toplam iş tecrübesi bakımından tanımlanan boyutlar açısından fark olup olmadığı hipotezleri ile araştırılmıştır. Bu hipotezler detaylı olarak bölüm 4 de tartısılacaktır. 


\section{Evren ve Örneklem}

Araştırmanın evrenini, Kocaeli Organize Sanayi Bölgesi’nde çalışan ve aynı zamanda Y kuşağında yer alan kişiler oluşturmaktadır. Araştırmanın örneklemi, her bir katılımcıya eşit araştırmaya katılma şansı veren ve böylelikle hesaplamalarda her katılımcıya eşit ağırlık veren basit tesadüfi örneklem yöntemi ile edilmiştir (Arrkan, 2004, s. 141).

Araştırma için saha çalısması Ekim-Kasım 2018 tarihleri arasında Kocaeli Organize Sanayi Bölgesi'nde yapılmıştır. Araştırmada 280 katılımcıya ulaşılmıştır. İncelenen anket formların eksik ve hatalı olanlar analiz dışı tutulmuştur. Böylelikle toplam 271 kişinin verileri değerlendirmeye alınmıştır. Tablo 1 , araştırmaya katılan kişilerin demografik özelliklerini göstermektedir.

Tablo 1. Demografik Özellikler $(n=271)$

\begin{tabular}{|c|c|c|c|c|c|}
\hline $\begin{array}{l}\text { Değişken } \\
\text { Yaş }\end{array}$ & Frekans & Yüzde & $\begin{array}{c}\text { Değişken } \\
\text { İş Yerindeki Pozisyon }\end{array}$ & Frekans & Yüzde \\
\hline $18-22$ & 42 & 15,5 & Yarı Zamanlı Çalışan & 13 & 4,8 \\
\hline $23-27$ & 85 & 31,4 & Tam Zamanlı Çalıșan & 213 & 78,6 \\
\hline $28-32$ & 90 & 33,2 & Orta Kademe Yönetici & 29 & 10,7 \\
\hline $33-37$ & 54 & 19,9 & Üst Kademe Yönetici & 16 & 5,9 \\
\hline Ĕgitim Düzeyi & & & İş Yerindeki Çalışma Süresi & & \\
\hline Lise & 104 & 38,4 & 1 yıldan az & 49 & 18,1 \\
\hline Üniversite & 117 & 43,2 & $1-3 \mathrm{yll}$ & 212 & 78,2 \\
\hline YL/DR & 50 & 18,4 & $4-6 \mathrm{y} 1 \mathrm{l}$ & 10 & 3,7 \\
\hline Toplam İş Tecrübesi & & & Cinsiyet & & \\
\hline 1 yildan az & 53 & 19,6 & Erkek & 174 & 64,2 \\
\hline $1-3$ yil & 25 & 9,2 & Kadın & 97 & 35,8 \\
\hline $4-6$ yil & 58 & 21,4 & & & \\
\hline 7-9 yil & 55 & 20,3 & & & \\
\hline 10 yildan fazla & 80 & 29,5 & & & \\
\hline
\end{tabular}

Araştırmadaki katılımcıların \%64,2'isini erkeklerin ve \%35,8'ini ise kadınların oluşturduğu görülmektedir. Katıllimcların \%15,5'nin 18-22; \%31,4'ünün 23-27; \%33,2'sinin 28-32 ve \%19,9'unun 3337 yaş aralık gruplarında yer aldığı görülmüştür. Katılımcıların \%38,4'ünü lise, \%43,2'sini üniversite ve \%18,4'ünü ise yüksek lisans/doktora mezunlarının oluşturduğu gözlemlenmiştir. Katılımcıların iş yerindeki pozisyonlarına bakıldığında ise \%4,8'inin yarı zamanlı çalışanlar, \%78,6'sının tam zamanlı çalışanlar; $\% 10,7$ 'sinin orta kademe yöneticiler ve $\% 5,9$ 'unun ise üst kademe yöneticilerden oluştuğu görülmüştür. Katıllımcıların işyerindeki çalsşma süreleri incelendiğinde ise 1 yıldan az çalışanların \%18,1; 1 ile 3 yıl arası çalışanların \%78,2; 4 ile 6 yıl arası çalışanları ise \%3,7'lik orana sahip oldukları görülmüştür. Katılımcılar arasında toplam iş tecrübesi 1 yıldan az olanların \%19,6; 1 ile 3 yil arasında olanların \%9,2; 4 ile 6 yll arasına olanların \%21,4; 7 ile 9 yıl arasinda olanların $\% 20,3$ ve 10 yıldan fazla olanların oranı ise $\% 29,5$ tir.

\section{Araştırmada Kullanılan Ölçeklerin Hazırlanması}

Çalışmanın alan araştırmasında anket formu kullanılmıştır. Araştırmada kullanılan "kariyer algısı" ve "gelecek beklentisi” ölçekleri ilk defa araştırmacılar tarafından geliştirilmiş olup, konu hakkındaki literatür esas alınmışır. Uygulamada kullanılan anket formu 3 bölümden oluşmaktadır. İlk bölümde, araştırma hedef kitlesi olarak, Kocaeli Organize Sanayi Bölgesi’nde çalışan Y kuşağında yer alan kişilerin demografik özelliklerini belirlemeye yönelik sorular yer almıştır. İkinci bölümde ise Y kuşağı bireylerinin kariyer algısı saptanmaya çalışılmıştır. Son bölümde ise Y kuşağının gelecek beklentisi incelenmiştir.

5'li likert türündeki ifadeler olumsuzdan olumluya olmak üzere "kesinlikle katılmiyorum", "katılmıyorum", "kararsızım", "katılıyorum", "kesinlikle katılıyorum" şeklinde sınıflandırılmıştır. Kariyer algısı için 20, gelecek beklentisi için 20 ölçek ifadesi hazırlanmıştır.

Araştırma ölçekleri uygulanmadan önce $\mathrm{Y}$ kuşağındaki 20 kişiye pilot uygulama yapılarak ortaya çıkması muhtemel sorunlar giderilmiştir. Bu pilot çalışmanın sayısının yeterli olduğu düşünülmektedir (Balcı, 2001; Altunış1k, Çoşkun, Bayraktaroğlu ve Yıldırım, 2005). Pilot araştırma neticesinde ölçeklerin güvenilirliğini artırmak amacılla kariyer alg1sı ve gelecek beklentisi ölçeklerinden birer ifade çıkarılarak, ifade sayıs1 19 olacak şekilde yeniden düzenlenmiştir. Böylelikle katılımcılara kariyer algisı için 19, gelecek beklentisi için 19 ifade yöneltilmiştir. Son şekli verilen anket formunda 6's1 demografik, 38'i likert tipi olmak üzere toplam 44 ifade bulunmaktadır. 


\section{Bulgular}

\section{Ölçek Geçerliliği ve Güvenilirliği}

Araştırmada hazırlanan ölçeklerin yap1 geçerliliği açıklayıcı faktör analizi ile değerlendirilmiştir. Ölçeklerde doğrudan gözlenen ifadeler esas alınarak; doğrudan gözlenemeyen değişkenlere ait yapının belirlenmesinde kariyer algisı ve gelecek beklentisi bölümlerindeki ifadeler boyutlara indirgenmiştir (Patır, 2009; Bektaş ve Akman, 2013; Özdemir, Gökdağ ve Neslihanoğlu, 2019).

Kariyer alg1sı ölçeği faktör analizi sonucunda, ölçekte bulunan 19 ifade toplamda 3 boyuta (faktöre) indirgenmiştir. Bu boyutlar sırasıyla "motivasyon", "uyum" ve "plan" olarak adlandırılmıştır. Bu 3 boyut, toplam varyansın \%71,53'ünü açıklamaktadır. Elde edilen bu toplam varyans yüzdesi çok faktörlü durumlarda açıklanan yeterli yüzde olarak kabul edilebilir (Çokluk, Şekercioğlu, Büyüköztürk, 2012, s. 245). Bu varyans açıklama oranına \%26,39'u ile motivasyon boyutu, \%25,07'si ile uyum boyutu ve \%20,07'si ile plan boyutunun sahip olduğu görülmüştür. Bu durumda katıllımcılarının kariyer algısı konusunda en az önemi plan boyutuna verdiğini gözlenmektedir. Tablo 2'de kariyer algısı ölçeği için döndürülmüş bileşenler matrisi sonucu oluşturulan 3 boyutun her biri için belirlenen ölçek ifadeleri gösterilmiştir.

Tablo 2'deki kariyer alg1s1 için döndürülmüş bileşenler matrisi yüklerinin 4 ölçek ifadesi haricinde 0,70 ve üzeri olmasından dolayı bu ifadelerin mükemmel değişim gösterdiği söylenebilir (Dede ve Yaman, 2008, s. 27).

Kariyer alg1sı ölçeği için faktör analizinin uygunluğunu test etmek için KMO (Kaiser-Meyer-Olkin) ve Bartlett testi sonuçlarına bakılmıştır. KMO test sonucu 0,932 değeriyle örneklem büyüklüğünün mükemmel düzeyde olduğunu ve Bartlett testi sonucu $0,000(\mathrm{p}=0,000<0,05)$ anlamlılık değeriyle ölçek ifadelerinin faktör analizi için uygun olduğunu göstermiştir (Durmuş, Çinko ve Yurtkoru, 2016, s. 89).

Tablo 2. Kariyer Algısı Ölçeği Faktör Analizi Sonuclar

\begin{tabular}{|c|c|c|c|c|}
\hline \multirow{2}{*}{ Boyut } & \multirow{2}{*}{ İfadeler } & \multicolumn{3}{|c|}{ Bileşen } \\
\hline & & 1 & 2 & 3 \\
\hline \multirow{7}{*}{ Motivasyon } & İş yerimin sağladığı maddi imkanların yeterli olduğunu düşünüyorum. & ,860 & & \\
\hline & Kendimi gelecekte daha yüksek bir statüde görüyorum. & ,853 & & \\
\hline & İş yerimdeki çalışmalarımın ödüllendirilmesi beni motive eder. & 840 & & \\
\hline & Kariyerimi ekonomik olarak planladım. & ,827 & & \\
\hline & Bulunduğum pozisyondan daha iyi bir pozisyonu hak ettiğimi düşünüyorum. & ,775 & & \\
\hline & İş yerim kariyerime odaklanma konusunda beni etkiler. & ,692 & & \\
\hline & İş yerimdeki maddi ve manevi çalışmalarımın karşılığını aldığımı düşünüyorum. &, 593 & & \\
\hline \multirow{7}{*}{ Uyum } & Kariyer planımdaki hedeflerime ulaştığımı düşünüyorum. & & 825 & \\
\hline & Hedeflediğim kariyer planımdaki işte çalıştığımı düşünüyorum. & & 809 & \\
\hline & $\begin{array}{l}\text { İş yerimde kazandığım tecrübelerimin kariyerim için yeterli olduğunu } \\
\text { düşünüyorum. }\end{array}$ & & ,789 & \\
\hline & Seçtiğim kariyer alanının bireysel beklentilerime cevap verdiğini düşünüyorum. & & ,777 & \\
\hline & İş yerimin hedeflediğim kariyer ile uyumlu olduğunu düşünüyorum. & & ,725 & \\
\hline & Planladığım kariyer üzerine çalıştı̆̆ımı düşünüyorum. & & 689 & \\
\hline & İş yerimin bana uygun bir vizyonu olduğunu düşünüyorum. & & 626 & \\
\hline \multirow{7}{*}{ Plan } & Kariyer hedeflerim arasında olmasa da çalıştı̆̆ım işten memnunum. & & & 811 \\
\hline & Kariyer planım ile ilgili hata yaptığımı düşünmüyorum. & & & ,808 \\
\hline & Kariyer planımda başarılı olduğumu düşünüyorum. & & & ,806 \\
\hline & İlgi alanlarımın çoğunu kariyerimle ilgili konular oluşturur. & & & ,764 \\
\hline & & & & ,730 \\
\hline & & \multicolumn{2}{|c|}{ KMO Değeri } & ,932 \\
\hline & Bartlett's Küresellik Testi & & $\begin{array}{l}\text { Kare } \\
\text { eğeri }\end{array}$ & $\begin{array}{c}4005,925 \\
, 000\end{array}$ \\
\hline
\end{tabular}

Gelecek beklentisi ölçeği faktör analizi sonucunda, ölçekte yer alan 19 ifade toplamda 4 boyuta (faktöre) indirgenmiş ve sırasıyla "teknoloji ve sosyalleşme", "ortam", "ilisşkiler" ve "iş değiştirme" olarak adlandırılmışır. Bu 4 boyutun toplam varyansın \%69'unu açıkladığı tespit edilmiştir. Bu varyans açıklama oranına \%21,04'ü ile teknoloji ve sosyalleşme boyutu, \%19,78'i ile ortam boyutu, \%16,91'i ile ilişkiler boyutu ve \%11,27'si ile iş değiştirme boyutunun sahip olduğu görülmüştür. Bu durumda katılımcılarının gelecek beklentisi konusunda en fazla önemi teknoloji ve sosyalleşme boyutuna verirken; en az önemi iş değiştirme boyutuna verdiğini görülmüştür. Tablo 3 , gelecek beklentisi ölçeği için döndürülmüş bileşenler matrisi sonucu 4 boyut olarak belirlenen ölçek ifadelerini yer aldıkları boyutlar bakımından göstermektedir. 
Tablo 3. Gelecek Beklentisi Ölçeği Faktör Analiz̨i Sonuçlar

\begin{tabular}{|c|c|c|c|c|c|}
\hline \multirow{2}{*}{ Boyut } & \multirow{2}{*}{ İfadeler } & \multicolumn{4}{|c|}{ Bileşen } \\
\hline & & 1 & 2 & 3 & 4 \\
\hline \multirow{6}{*}{$\begin{array}{l}\text { Teknoloji } \\
\text { ve } \\
\text { Sosyalleşme }\end{array}$} & İş yerimin teknolojik imkanlar sunduğunu düşünüyorum. & 7,797 & & & \\
\hline & İş yerimin teknolojik bir altyapıya sahip olması önemlidir. &, 792 & & & \\
\hline & İş yerimdeki teknolojinin yeterli olduğunu düşünüyorum. &, 787 & & & \\
\hline & İş yerimin sosyal aktivitelere önem verdiğini düşünüyorum. & ,656 & & & \\
\hline & $\begin{array}{l}\text { İş yerimin sağladığı sosyal aktivitelerin başarıma katkısı } \\
\text { olduğunu düșünüyorum. }\end{array}$ & ,646 & & & \\
\hline & İş yerimdeki sosyal olanakların yeterli olduğunu düşünüyorum. & ,643 & & & \\
\hline \multirow{6}{*}{ Ortam } & İş yerimde fikirlerimi özgürce ifade edebilmem önemlidir. & & ,758 & & \\
\hline & İş yerimde yoğun çalışma kuralları olduğunu düşünüyorum. & &, 753 & & \\
\hline & $\begin{array}{l}\text { İş yerimdeki esnek çalışma saatlerinin yeterli olduğunu } \\
\text { düșünüyorum. }\end{array}$ & &, 749 & & \\
\hline & $\begin{array}{l}\text { İş yerimdeki çalışma ortamının adaletli olduğunu } \\
\text { düşünüyorum. }\end{array}$ & & ,725 & & \\
\hline & $\begin{array}{l}\text { İşyerimdeki çalışma ortamının önemli olduğunu } \\
\text { düşünüyorum. }\end{array}$ & & 631 & & \\
\hline & $\begin{array}{l}\text { İs yerimdeki çalışma ortamının sade ve yalın olduğunu } \\
\text { düşünüyorum. }\end{array}$ & & ,561 & & \\
\hline \multirow{5}{*}{ İlişkiler } & Yöneticim, beni ve mesleki farklılıklarımı yeterince bilir. & & &, 762 & \\
\hline & $\begin{array}{l}\text { Yöneticim, yaptığım iş konusunda beni, düzenli olarak } \\
\text { bilgilendirir ve takdir eder. }\end{array}$ & & & ,743 & \\
\hline & İş yerinde kendimi değerli hissediyorum. & & & ,711 & \\
\hline & Kariyerim ile ilgili geleceğimden endişeleniyorum. & & & 610 & \\
\hline & Yöneticim beni kariyerimde ilerleme konusunda teşvik eder. & & &, 541 & \\
\hline \multirow{4}{*}{$\begin{array}{l}\text { İş } \\
\text { Değiştirme }\end{array}$} & $\begin{array}{l}\text { İş yerimdeki çalışma ortamının sağlığım için riskli olduğunu } \\
\text { düşünüyorum. }\end{array}$ & & & & ,808 \\
\hline & Kariyer planımdaki hedeflerim için risk alabilirim. & & & &, 754 \\
\hline & & & \multicolumn{2}{|c|}{ KMO Değeri } & ,944 \\
\hline & & \multicolumn{2}{|c|}{ Bartlett's Küresellik Testi } & $\begin{array}{l}\text { Ki-Kare } \\
\text { p Değeri }\end{array}$ & $\begin{array}{c}3235,847 \\
, 000\end{array}$ \\
\hline
\end{tabular}

Tablo 3’teki sonuçlara göre gelecek beklentisi ölçeği için oluşturulan döndürülmüş bileşenler matrisi yüklerinin 2 ölçek ifadesi haricinde 0,70 civarında ve üzeri olmasından dolayı bu ifadelerin mükemmel değişim gösterdiği söylenebilir (Dede ve Yaman, 2008, s. 27).

Gelecek beklentisi ölçeğinin KMO değeri 0,944 ve Bartlett testi sonucu $0,000 \quad(p=0,000<0,05)$ anlamlılık değeriyle ölçek ifadelerinin faktör analizi için uygun olduğu saptanmaktadır.

Tablo 4, kariyer algısı ve gelecek beklentisi ölçeklerinin güvenilirlik analizi sonuçlarını göstermektedir. Güvenilirlik analizlerinde Cronbach's Alfa değeri kullanılmıştır. Cronbach's Alpha değerinin minimum 0,60 olması esas alınmıştır (Cronbach, 1990; Punch, 2005). Elde edilen güvenilirlik katsayıları 0,680 ile 0,947 arasında değişmektedir. Bu değerler, ölçek ifadelerinin içsel tutarlıllğı olduğunu göstermektedir.

Tablo 4. Güvenilirlike Analizi Sonuclar

\begin{tabular}{lcc}
\hline \multicolumn{1}{c}{ Değişkenler } & Soru Sayıs & Cronbach's Alpha Değeri \\
\hline Motivasyon & 7 & 0,867 \\
Uyum & 7 & 0,860 \\
Plan & 5 & 0,796 \\
Kariyer Algisı & 19 & 0,947 \\
\hline Teknoloji ve Sosyalleşme & 6 & 0,845 \\
Ortam & 6 & 0,874 \\
İliskiler & 5 & 0,819 \\
İș Değiştirme & 2 & 0,680 \\
Gelecek Beklentisi & 19 & 0,945 \\
\hline
\end{tabular}

\section{Ölçek İfadelerinin Betimsel Bulguları}

Kariyer algisı ölçeğindeki ifadelerin yüzde dağılımı, ortalama ve standart sapma sonuçları Tablo 5'te görülmektedir. Araştırma sonuçlarına göre, katılımcıların ölçek ifadelerine verdikleri yanıtların ortalaması yaklaşık olarak 4 (katılıyorum) olurken; standart sapmaları yaklaşık olarak 0,9 olarak gözlemlenmiştir. Katılımcıların en çok hem fikir oldukları \% 45,8 oranla kesinlikle katılıyorum ile "Kariyer planımda başarılı olduğumu düşünüyorum." ifadesi olmuştur. Buna ek olarak, katıllmcilar en az olarak hem fikir oldukları 
ifade ise $\% 0,7$ oranla katılmıyorum ile "Kariyer planım ile ilgili hata yaptığımı düşünüyorum." olarak belirtilmiştir.

Tablo 5. Kariyer Algısı Ölçek İfadeleri İ̧̧in Betimsel Bulgular (n=271)

\begin{tabular}{|c|c|c|c|c|c|c|c|}
\hline İfadeler & (1) & $(2)$ & (3) & (4) & (5) & Ort. & Std.Sp. \\
\hline $\begin{array}{l}\text { İssyerimin hedeflediğim kariyer ile uyumlu olduğunu } \\
\text { düșünüyorum. }\end{array}$ & 2,1 & 4,1 & 22,5 & 41,0 & 30,3 & 3,93 & 0,94 \\
\hline $\begin{array}{l}\text { İşyerimde kazandığım tecrübelerimin kariyerim için } \\
\text { yeterli olduğunu düşünüyorum. }\end{array}$ & 3,1 & 6,6 & 17,3 & 41,7 & 31,3 & 3,90 & 1,02 \\
\hline $\begin{array}{l}\text { Kendimi gelecekte daha yüksek bir statüde } \\
\text { görüyorum. }\end{array}$ & 1,4 & 3,7 & 19,6 & 35,4 & 39,9 & 4,09 & 0,93 \\
\hline $\begin{array}{l}\text { İlgi alanlarımın çoğunu kariyerimle ilgili konular } \\
\text { oluşturur. }\end{array}$ & 1,1 & 2,6 & 15,1 & 43,9 & 37,3 & 4,14 & 0,84 \\
\hline $\begin{array}{l}\text { İşyerimin sağladığı maddi imkanların yeterli olduğunu } \\
\text { düşünüyorum. }\end{array}$ & 1,9 & 3,3 & 22,9 & 36,5 & 35,4 & 4,00 & 0,94 \\
\hline Kariyer planım ile ilgili hata yaptığımı düşünüyorum. & 1,9 & 0,7 & 17,0 & 36,9 & 43,5 & 4,20 & 0,87 \\
\hline $\begin{array}{l}\text { İşyerimin bana uygun bir vizyonu olduğunu } \\
\text { düşünüyorum. }\end{array}$ & 2,2 & 4,4 & 19,2 & 39,1 & 35,1 & 4,00 & 0,96 \\
\hline $\begin{array}{l}\text { İşyerim kariyerime odaklanma konusunda beni } \\
\text { etkiler. }\end{array}$ & 1,5 & 5,5 & 16,2 & 40,6 & 36,2 & 4,04 & 0,94 \\
\hline Planladığım kariyer üzerine çalıştığımı düşünüyorum. & 2,5 & 2,6 & 17,0 & 42,1 & 35,8 & 4,06 & 0,93 \\
\hline $\begin{array}{l}\text { Kariyer hedeflerim arasında olmasa da çalıştı̆̆ım işten } \\
\text { memnunum. }\end{array}$ & 0,8 & 1,8 & 17,3 & 35,8 & 44,3 & 4,21 & 0,85 \\
\hline $\begin{array}{l}\text { İşyerimdeki maddi ve manevi çalışmalarımın } \\
\text { karşılığını aldığımı düşünüyorum. }\end{array}$ & 2,5 & 3,7 & 20,7 & 37,3 & 35,8 & 4,00 & 0,97 \\
\hline Kariyer planımda başarılı olduğumu düşünüyorum. & 1,0 & 2,6 & 15,9 & 34,7 & 45,8 & 4,21 & 0,88 \\
\hline $\begin{array}{l}\text { Hedeflediğim kariyer planımdaki işte çalıştı̆̆ımı } \\
\text { düşünüyorum. }\end{array}$ & 1,7 & 4,1 & 17,0 & 41,0 & 36,2 & 4,06 & 0,93 \\
\hline Kariyerimi ekonomik olarak planladım. & 1,9 & 5,9 & 17,7 & 33,9 & 40,6 & 4,06 & 0,99 \\
\hline $\begin{array}{l}\text { Seçtiğim kariyer alanının bireysel beklentilerime cevap } \\
\text { verdiğini düşünüyorum. }\end{array}$ & 3,3 & 6,6 & 21,8 & 41,0 & 27,3 & 3,82 & 1,01 \\
\hline Planladığım kariyer üzerine çalıştığımı düşünüyorum. & 1,1 & 1,8 & 13,3 & 44,3 & 39,5 & 4,19 & 0,82 \\
\hline $\begin{array}{l}\text { Bulunduğum pozisyondan daha iyi bir pozisyonu hak } \\
\text { ettiğimi düşünüyorum. }\end{array}$ & 1,1 & 4,1 & 18,8 & 36,9 & 39,1 & 4,09 & 0,92 \\
\hline $\begin{array}{l}\text { Kariyer planımdaki hedeflerime ulaştı̆̆ımı } \\
\text { düşünüyorum. }\end{array}$ & 1,1 & 6,3 & 17,3 & 40,6 & 34,7 & 4,02 & 0,94 \\
\hline $\begin{array}{l}\text { İssyerimdeki çalışmalarımın ödüllendirilmesi beni } \\
\text { motive eder. }\end{array}$ & 1,5 & 3,7 & 21,0 & 35,1 & 38,7 & 4,06 & 0,94 \\
\hline
\end{tabular}

Not: (1) Kesinlikle Katılmıyorum, (2) Katılmıorum, (3) Kararsızım, (4) Katılıyorum ve (5) Kesinlikle Katılıyorum, (Ort.) Ortalama ve (Std. Sp.) Standart Sapma şeklinde tanımlanmıştır.

Tablo 6'da gelecek beklentisi ölçek ifadelerinin yüzde dağılımı, ortalama ve standart sapma sonuçları sunulmaktadır. Sonuçlar incelendiğinde, katılımcılar tarafindan ölçek ifadelerine verilen yanıtların ortalaması yaklaşı olarak 4 (katıllyorum) olurken; standart sapmaları yaklaşı olarak 0,9 olarak gözlemiştir. Katılımcıların \%43,2 oranda en çok hem fikir oldukları "İşyerimdeki teknolojinin yeterli olduğunu düşünüyorum." ifadesi olmuştur. 
Tablo 6. Gelecek Beklentisi Ölçek Ifadeleri Ị̇in Betimsel Bulgular (n=271)

\begin{tabular}{|c|c|c|c|c|c|c|c|}
\hline İfadeler & (1) & $(2)$ & (3) & (4) & (5) & Ort. & Std.Sp. \\
\hline $\begin{array}{l}\text { İşyerimdeki esnek çalışma saatlerinin yeterli olduğunu } \\
\text { düşünüyorum. }\end{array}$ & 1,1 & 4,8 & 20,7 & 40,6 & 32,8 & 3,99 & 0,91 \\
\hline $\begin{array}{l}\text { Yöneticim, yaptı̆̆ım iş konusunda beni düzenli olarak } \\
\text { bilgilendirir ve takdir eder. }\end{array}$ & 1,1 & 4,1 & 17,7 & 34,7 & 42,4 & 4,13 & 0,92 \\
\hline $\begin{array}{l}\text { İş yerimdeki sosyal olanakların yeterli olduğunu } \\
\text { düşünüyorum. }\end{array}$ & 0,7 & 4,1 & 19,9 & 37,3 & 38,0 & 4,08 & 0,89 \\
\hline $\begin{array}{l}\text { İş yerimdeki çalışma ortamının önemli olduğunu } \\
\text { düşünüyorum. }\end{array}$ & 0,7 & 4,1 & 25,1 & 38,0 & 32,1 & 3,97 & 0,89 \\
\hline Kariyer planımdaki hedeflerim için risk alabilirim. & 4,3 & 6,3 & 18,3 & 32,5 & 38,4 & 3,94 & 1,10 \\
\hline $\begin{array}{l}\text { İş yerimde fikirlerimi özgürce ifade edebilmem } \\
\text { önemlidir. }\end{array}$ & 1,9 & 2,2 & 14,4 & 40,2 & 41,3 & 4,16 & 0,89 \\
\hline İş yerinde kendimi değerli hissediyorum. & 1,4 & 2,6 & 19,6 & 35,1 & 41,3 & 4,12 & 0,91 \\
\hline $\begin{array}{l}\text { İş yerimin sağladığı sosyal aktivetelerin başarıma } \\
\text { katkısı olduğunu düşünüyorum. }\end{array}$ & 1,8 & 4,1 & 22,1 & 39,9 & 32,1 & 3,96 & 0,93 \\
\hline $\begin{array}{l}\text { İş yerimdeki çalışma ortamının sade ve yalın } \\
\text { olduğunu düşünüyorum. }\end{array}$ & 3,0 & 2,2 & 21,0 & 38,7 & 35,1 & 4,00 & 0,96 \\
\hline $\begin{array}{l}\text { Yöneticim beni kariyerimde ilerleme konusunda } \\
\text { teşvik eder. }\end{array}$ & 1,1 & 1,5 & 20,7 & 38,7 & 38,0 & 4,11 & 0,86 \\
\hline $\begin{array}{l}\text { İş̧ yerimde yoğun çalışma kuralları olduğunu } \\
\text { düşünüyorum. }\end{array}$ & 1,2 & 3,3 & 23,6 & 39,1 & 32,8 & 3,99 & 0,89 \\
\hline $\begin{array}{l}\text { İş yerimin teknolojik bir altyapıya sahip olması } \\
\text { önemlidir. }\end{array}$ & 1,4 & 5,2 & 19,6 & 37,3 & 36,5 & 4,02 & 0,95 \\
\hline $\begin{array}{l}\text { İş yerimdeki çalsşma ortamının sağlı̆̆ım için riskli } \\
\text { olduğunu düşünüyorum. }\end{array}$ & 7,7 & 11,1 & 18,5 & 32,1 & 30,6 & 3,67 & 1,23 \\
\hline $\begin{array}{l}\text { Yöneticim, beni ve mesleki farklılıklarımı yeterince } \\
\text { bilir. }\end{array}$ & 1,8 & 4,8 & 17,0 & 34,7 & 41,7 & 4,10 & 0,97 \\
\hline $\begin{array}{l}\text { İş yerimdeki teknolojinin yeterli olduğunu } \\
\text { düşünüyorum. }\end{array}$ & 0,4 & 5,5 & 17,0 & 33,9 & 43,2 & 4,14 & 0,92 \\
\hline $\begin{array}{l}\text { İş yerimin sosyal aktivitelere önem verdiğini } \\
\text { düsünüyorum. }\end{array}$ & 0,8 & 4,4 & 16,6 & 40,6 & 37,6 & 4,10 & 0,88 \\
\hline Kariyerim ile ilgili geleceğimden endişeleniyorum. & 1,1 & 3,3 & 17,7 & 37,3 & 40,6 & 4,13 & 0,89 \\
\hline $\begin{array}{l}\text { İş yerimin teknolojik imkanlar sunduğunu } \\
\text { düşünüyorum. }\end{array}$ & 1,1 & 4,4 & 19,2 & 36,9 & 38,4 & 4,07 & 0,92 \\
\hline
\end{tabular}

Not: (1) Kesinlikle Katılmıyorum, (2) Katılmiyorum, (3) Kararsızım, (4) Katılıorum ve (5) Kesinlikle Katıllyorum, (Ort.) Ortalama ve (Std. Sp.) Standart Sapma şeklinde tanımlanmıştır.

\section{Farklılık Analizleri}

Her bir ölçek için oluşturulan boyutlar bakımından gruplar arası farklılı̆̆ ölçmek için bağımsız örneklem testi (t-testi) ve varyans analizi (tek yönlü ANOVA) kullanılmıştır. Eğer ki farklılık gözlenmiş ise bu farklılığın kaynağını bulmak için ise Scheffe testi ile çoklu karşılaştırmalar ve çıkarımlar yapilmıştır.

\section{Cinsiyete Göre Farkl111k Analizi}

Cinsiyet bakımından kariyer algısı ölçek ifadelerinin her bir boyutu için verilen puan ortalamalarının arasında fark olup olmadığı hipotezi aşağıda verilmiştir.

$\mathbf{H}_{0}$ : Kariyer algisı konusunda cinsiyet bakımından $i$. boyut (faktör) puan ortalamaları arasında fark yoktur.

$\mathbf{H}_{\mathrm{A}}$ : Kariyer algısı konusunda cinsiyet bakımından $i$. boyut (faktör) puan ortalamaları arasında fark vardir.

Buradaki $i$. boyut motivasyon, uyum ve plan boyutu olarak ayrı ayrı tanımlanmıştır. Bu hipotezler ayr1 ayrı eşit varyanslar varsayımı veya eşit olmayan varyanslar varsayımı altında $\% 95$ güvenilirlik düzeyinde bağımsız örneklem testi (t-testi) ile test edilmiştir. Test sonuçlarına Tablo 7'de yer verilmiştir 
Tablo 7. Cinsiyete Göre Bağımsız Ömeklemler Testi (t-testi) - Kariyer Algısı

\begin{tabular}{|c|c|c|c|c|c|c|}
\hline & & \multicolumn{2}{|c|}{ Levene Testi } & \multicolumn{3}{|c|}{$\begin{array}{c}\text { Ortalamaların eşitliği } \\
\text { t-testi }\end{array}$} \\
\hline & & F & $p$ & $\mathbf{t}$ & df & $p$ (2-yönlü) \\
\hline Motivasyon & Eşit Varyanslar Varsayımı &, 047 & ,828 & $-3,037$ & 269 &, $003 *$ \\
\hline Uyum & Eşit Varyanslar Varsayımı & 1,661 & ,199 & $-1,951$ & 269 & 052 \\
\hline Plan & $\begin{array}{l}\text { Eşit Olmayan } \\
\text { Varyanslar Varsayımı }\end{array}$ & 4,824 & 029 &,- 720 & 243,319 & , 472 \\
\hline
\end{tabular}

* \%95 güvenilirlik düzeyinde anlamlıdır.

Tablo 7'deki test sonuçlarına göre uyum $(p=0,052>0.05)$ ve plan $(p=0,472>0.05)$ boyutlarında cinsiyet bakımından fark olmadığ1; motivasyon $(\mathrm{p}=0,03<0.05)$ boyutunda ise cinsiyet bakımından fark olduğu \%95 güvenilirlik düzeyinde söylenebilir. Sonuç olarak, kadın ve erkek katılımcılar uyum ve plan boyutları bakımından benzer düşünceye sahiplerken; motivasyon boyutu bakımından farklı düşüncelere sahip oldukları görülmüştür. Elde edilen bulgulara göre kadınların motivasyon düzeyi erkeklerden daha yüksek olduğu saptanmıştır.

Cinsiyet bakımından gelecek beklentisi ölçeğine her bir boyut için verilen puan ortalamalarının arasında fark olup olmadığı hipotezleri aşağıda tanımlanmıştır.

$\mathbf{H}_{0}$ : Gelecek beklentisi konusunda cinsiyet bakımından $i$. boyut (faktör) puan ortalamaları arasında fark yoktur.

$\mathbf{H}_{\mathrm{A}}$ : Gelecek beklentisi konusunda cinsiyet bakımından $i$. boyut (faktör) puan ortalamaları arasında fark vardır.

Buradaki i. boyut teknoloji ve sosyalleşme, ortam, ilişkiler ve iş değiştirme boyutu olarak ayrı ayrı tanımlanmıştır. Bu hipotezler ayrı ayrı eşit varyanslar varsayımı veya eşit olmayan varyanslar varsayımı altında \%95 güvenilirlik düzeyinde bağımsız örneklem testi (t-testi) ile test edilmiş ve sonuçlara Tablo 8'de yer verilmiştir.

Tablo 8. Cinsiyete Göre Bağımsız Örneklemler Testi (t-testi) - Gelecek Beklentisi

\begin{tabular}{lllcccc}
\hline & & \multicolumn{2}{c}{ Levene Testi } & \multicolumn{3}{c}{ Ortalamaların eşitliği } \\
& & F & $\boldsymbol{p}$ & $\mathbf{t}$ & $\mathbf{d f}$ & $\boldsymbol{p}$ (2-yönlü) \\
\hline $\begin{array}{l}\text { Teknoloji ve } \\
\text { Sosyalleşme }\end{array}$ & Eşit Varyanslar Varsayımı &, 765 &, 382 & $-2,034$ & 269 &, $043^{*}$ \\
\hline Ortam & Eşit Varyanslar Varsayımı &, 864 &, 354 & $-2,455$ & 269 &, $015^{*}$ \\
\hline İlişkiler & $\begin{array}{l}\text { Eşit Olmayan } \\
\text { Varyanslar Varsayımı }\end{array}$ & 7,630 &, $006^{*}$ & $-1,851$ & 252,078 &, 065 \\
\hline İş Değiştirme & Eşit Varyanslar Varsayımı & 2,339 &, 127 & $-2,261$ & 269 &, $025^{*}$ \\
\hline
\end{tabular}

*\%95 güvenilirlik düzeyinde anlamlıdır.

Tablo 8'deki test sonuçlarına göre, sadece ilişkiler boyutunda $(p=0,065>0,05)$ cinsiyet bakımından fark olmadığı \%95 güvenilirlik düzeyinde söylenebilir. Sonuç olarak, kadın ve erkek katılımcılar sadece ilişkiler boyutu bakımından benzer düşünceye sahiplerken; teknoloji ve sosyalleşme, ortam ve iş değiştirme boyutu bakımından farklı düşüncelere sahip oldukları görülmüştür. Analiz sonuçlarına göre kadınların teknoloji ve sosyalleşme, ortam ve iş değiştirme durumları erkeklere göre daha fazla olduğu belirlenmiştir.

\section{Eğitim Düzeyine Göre Farklılık Analizi}

Eğitim düzeyi bakımından kariyer algısı ölçeğine verilen puan ortalamalarının arasında fark olup olmadığ1 hipotezleri aşağıda verilmiştir.

$\mathbf{H}_{\mathbf{0}}$ : Kariyer alg1sı konusunda eğitim düzeyi bakımından gruplar arasında $i$. boyut (faktör) puan ortalamaları arasında fark yoktur. 
$\mathbf{H}_{\mathrm{A}}$ : Kariyer alg1sı konusunda eğitim düzeyi bakımından gruplar arasında $i$. boyut (faktör) puan ortalamaları arasında fark vardır.

Buradaki i. boyut motivasyon, uyum ve plan boyutu bakımından ayrı ayrı tanımlanmıștır. Her bir boyunun hipotezleri $\% 95$ güvenilirlik düzeyinde varyans analizi (tek yönlü ANOVA) testi ile test edilmiştir. Test sonuçlarına Tablo 9'da yer verilmiştir.

Tablo 9. Eğitim Düzeyine Göre Varyans Analizi (Tek Yönlü ANOV A) - Kariyer Algısı

\begin{tabular}{|c|c|c|c|c|c|c|}
\hline & & Kareler Top. & $\begin{array}{c}\text { Serbestlik } \\
\text { Derecesi }\end{array}$ & Kareler Ort. & F & $\mathrm{p}$ \\
\hline \multirow{3}{*}{ Motivasyon } & G.Aras1 & 10,899 & 2 & 5,449 & 5,637 & ,004* \\
\hline & G.İçi & 259,101 & 268 & 967 & & \\
\hline & Toplam & 270,000 & 270 & & & \\
\hline \multirow{3}{*}{ Uyum } & G.Aras1 & 13,198 & 2 & 6,599 & 6,887 & ,001* \\
\hline & G.İçi & 256,802 & 268 & ,958 & & \\
\hline & Toplam & 270,000 & 270 & & & \\
\hline \multirow{3}{*}{ Plan } & G.Aras1 & 1,044 & 2 &, 522 &, 520 & ,595 \\
\hline & G.İçi & 268,956 & 268 & 1,004 & & \\
\hline & Toplam & 270,000 & 270 & & & \\
\hline
\end{tabular}

Tablo 9'daki test sonuçlarına göre, kariyer algısı eğitim düzeyi bakımdan gruplar arasında motivasyon $(\mathrm{p}=0,004<0,05)$ ve uyum $(\mathrm{p}=0,001<0,05)$ boyutları açısından fark olduğu ve plan $(\mathrm{p}=0,595>0,05)$ boyutu açısından ise fark olmadığ $\% 95$ güvenilirlik düzeyinde saptanmaktadır. Sonuç olarak, katılımcıların kariyer alg1sı konusunda eğitim düzeyi grupları arasında motivasyon ve uyum boyutu açısından farklı düşüncelere sahip oldukları söylenebilir.

Kariyer alg1sı konusundaki bu farkın hangi eğitim düzeyi grupları arasında olduğunu tespit etmek için aşağıdaki hipotezler tanımlanmışır.

$\mathbf{H}_{0}$ : Kariyer algısı konusundan eğitim düzeyi $j$ grubu ile eğitim düzeyi $k$ grubu arasında $\mathrm{m}$ boyutu bakımından fark yoktur.

$\mathbf{H}_{\mathrm{A}}$ : Kariyer algisı konusundan eğitim düzeyi $j$ grubu ile eğitim düzeyi $k$ grubu arasında $\mathrm{m}$ boyutu bakımından fark vardır.

Buradaki, $\mathrm{j}$ ve $\mathrm{k}(\mathrm{j} \neq \mathrm{k}$ ) değişkenleri lise, üniversite ve $\mathrm{yl} / \mathrm{dr}$ ve $m$ değişkeni motivasyon ve uyum olarak ayrı ayrı tanımlanmıştır. Hipotezleri ise $\% 95$ güvenilirlik düzeyinde Scheffe testi ile çoklu karşılaştırmalar yapılmıstır. Tablo 10'da çoklu karşılaştırma test sonuçları verilmiştir.

Tablo 10. Scheffe Testi Sonuclar - Kariyer Algzsı

\begin{tabular}{lllccc}
\hline \multirow{2}{*}{ Değişken } & \multirow{2}{*}{ (j) Eğitim } & (k) Eğitim & $\begin{array}{c}\text { Ortalama Farki } \\
(j-k)\end{array}$ & Standart Hata & $p$ \\
\hline \multirow{2}{*}{ Motivasyon } & \multirow{2}{*}{ Üniversite } & Lise &, 332 &, 132 &, $034^{*}$ \\
& & YL/DR &, 500 &, 166 &, $008^{*}$ \\
\hline \multirow{2}{*}{ Uyum } & \multirow{2}{*}{ Lise } & Üniversite &,- 475 &, 131 &, $001^{*}$ \\
& & YL/DR &,- 116 &, 168 &, 769 \\
\hline
\end{tabular}

*\%95 güvenilirlik düzeyinde anlamlıdır.

Tablo 10'daki test sonuçlarına göre, üniversite mezunu Y kuşağı bireylerinin motivasyon düzeyi lise, yüksek lisans veya doktora mezunu kişilerden; uyum düzeyleri ise üniversite ve yüksek lisans/doktora mezunu kişilerin lise mezunu kişilerden daha yüksek olduğu tespit edilmektedir.

Eğitim düzeyi bakımından gelecek beklentisi ölçeğine verilen puan ortalamalarının arasında fark olup olmadığı hipotezleri aşağıda tanımlanmıştır.

$\mathbf{H}_{0}$ : Gelecek beklentisi konusunda eğitim düzeyi bakımından gruplar arasında $i$. boyut (faktör) puan ortalamaları arasinda fark yoktur.

$\mathbf{H}_{\mathrm{A}}$ : Gelecek beklentisi konusunda eğitim düzeyi bakımından gruplar arasında $i$. boyut (faktör) puan ortalamaları arasında fark vardır. 
Buradaki i. boyut teknoloji ve sosyalleşme, ortam, ilişkiler ve iş değiştirme boyutu bakımından ayrı ayrı tanımlanmıştır. Her bir boyunun hipotezleri \%95 güvenilirlik düzeyinde varyans analizi (tek yönlü ANOVA) test edilmiştir. Test sonuçlarına Tablo 11'de yer verilmiştir.

Tablo 11. Eğitim Düreyine Göre Varyans Analiæ̣ (Tek Yönlü ANOVA) - Gelecek Beklentisi

\begin{tabular}{|c|c|c|c|c|c|c|}
\hline & & $\begin{array}{c}\text { Kareler } \\
\text { Toplamı }\end{array}$ & $\begin{array}{c}\text { Serbestlik } \\
\text { Derecesi }\end{array}$ & $\begin{array}{c}\text { Kareler } \\
\text { Ortalamas1 }\end{array}$ & F & $p$ \\
\hline \multirow{3}{*}{$\begin{array}{l}\text { Teknoloji ve } \\
\text { Sosyalleşme }\end{array}$} & Gruplar Aras1 & 7,112 & 2 & 3,556 & 3,625 & ,028* \\
\hline & Gruplar İçi & 262,888 & 268 & 981 & & \\
\hline & Toplam & 270,000 & 270 & & & \\
\hline \multirow{3}{*}{ Ortam } & Gruplar Aras1 & 13,090 & 2 & 6,545 & 6,828 & ,001* \\
\hline & Gruplar İçi & 256,910 & 268 & ,959 & & \\
\hline & Toplam & 270,000 & 270 & & & \\
\hline \multirow{3}{*}{ İlişkiler } & Gruplar Aras1 & 923 & 2 & ,462 & 460 & ,632 \\
\hline & Gruplar İçi & 269,077 & 268 & 1,004 & & \\
\hline & Toplam & 270,000 & 270 & & & \\
\hline \multirow{3}{*}{ İş Değiştirme } & Gruplar Aras1 & 9,764 & 2 & 4,882 & 5,028 & ,007* \\
\hline & Gruplar İçi & 260,236 & 268 & 971 & & \\
\hline & Toplam & 270,000 & 270 & & & \\
\hline
\end{tabular}

Tablo 11'deki test sonuçlarına göre, gelecek beklentisi eğitim düzeyi bakımdan gruplar arasında sadece ilişkiler $(\mathrm{p}=0,632>0,05)$ boyutu açısından ise fark olmadığ1 $\% 95$ güvenilirlik düzeyinde söylenebilir. Sonuç olarak, gelecek beklentisi eğitim düzeyi bakımdan grupları arasında teknoloji ve sosyalleşme, ortam ve iş değiştirme boyutları açısından farklı düşüncelere sahip olduğu görülmüştür.

Gelecek beklentisi konusundaki bu farkın hangi eğitim düzey grupları arasında olduğunu tespit etmek için aşağıdaki hipotezler tanımlanmıştır.

$\mathbf{H}_{0}$ : Gelecek beklentisi konusundan eğitim düzeyi $j$ grubu ile eğitim düzeyi $k$ grubu arasında $\mathrm{m}$ boyutu bakımından fark yoktur.

$\mathbf{H}_{\mathrm{A}}$ : Gelecek beklentisi konusundan eğitim düzeyi $j$ grubu ile eğitim düzeyi $k$ grubu arasında $\mathrm{m}$ boyutu bakımından fark vardır.

Buradaki, $\mathrm{j}$ ve $\mathrm{k}(\mathrm{j} \neq \mathrm{k})$ değişkenleri lise, üniversite ve $\mathrm{yl} / \mathrm{dr}$ ve $m$ değişkeni teknoloji ve sosyalleşme, ortam ve iş değiştirme olarak ayrı ayrı tanımlanmıştır. Hipotezleri ise $\% 95$ güvenilirlik düzeyinde Scheffe testi ile çoklu karşılaştırma yapılmıştır. Tablo 12'de çoklu karşılaştırma test sonuçları verilmiştir.

Tablo 12. Scheffe Testi Sonuclar - Gelecek Beklentisi

\begin{tabular}{lllccc}
\hline \multicolumn{1}{c}{ Değişken } & \multirow{2}{*}{$(\mathbf{j})$ Ĕ̆itim } & (k) Ĕ̆itim & $\begin{array}{c}\text { Ortalama Farkı } \\
(\mathbf{j}-\mathbf{k})\end{array}$ & Standart Hata & $p$ \\
\hline Teknoloji ve Sosyalleşme & Üniversite & Lise &, 345 &, 133 &, $028^{*}$ \\
\hline \multirow{2}{*}{ Ortam } & \multirow{2}{*}{ YL/DR } & Lise &,- 436 &, 168 &, $027^{*}$ \\
& & Üniversite &,- 611 &, 165 &, $001^{*}$ \\
\hline \multirow{2}{*}{ İş Değiştirme } & Üniversite & Lise &, 421 &, 132 &, $005^{*}$ \\
\hline
\end{tabular}

Tablo 12'deki test sonuçlarına göre, üniversite mezunu Y kuşağı bireylerinin teknoloji ve sosyalleşme düzeyi ve iş değiştirme durumları lise mezunu kişilerden; ortama ilişkin gelecek beklentisi ise lise ve üniversite mezunu kişilerin yüksek lisans/doktora mezunu kişilerden daha yüksek olduğu tespit edilmektedir.

\section{İşyerindeki Pozisyona Göre Farklı1ık Analizi}

İşyerindeki pozisyon bakımından gelecek beklentisi ölçeğine verilen puan ortalamalarının arasında fark olup olmadığı hipotezleri aşağıda tanımlanmıştır.

$\mathbf{H}_{0}$ : Gelecek beklentisi konusunda işyerindeki pozisyon bakımından grupları arasında $i$. boyut (faktör) puan ortalamaları arasinda fark yoktur.

$\mathbf{H}_{\mathrm{A}}$ : Gelecek beklentisi konusunda issyerindeki pozisyon bakımından grupları arasında $i$. boyut (faktör) puan ortalamaları arasında fark vardır.

Burada $i$. boyut teknoloji ve sosyalleşme, ortam, ilişkiler ve iş değiştirme bakımından ayrı ayrı tanımlanmış ve hipotezleri $\% 95$ güvenilirlik düzeyinde varyans analizi (tek yönlü ANOVA) test edilmiş ve sonuçlar Tablo $13^{\prime}$ de verilmiştir. 
Tablo 13. Iss Yerindeki Pozisyona Göre Varyans Analizi (Tek Yönlü ANOVA) - Gelecek Beklentisi

\begin{tabular}{|c|c|c|c|c|c|c|}
\hline & & $\begin{array}{c}\text { Kareler } \\
\text { Toplamı }\end{array}$ & $\begin{array}{c}\text { Serbestlik } \\
\text { Derecesi }\end{array}$ & $\begin{array}{c}\text { Kareler } \\
\text { Ortalamas }\end{array}$ & F & $p$ \\
\hline \multirow{3}{*}{$\begin{array}{l}\text { Teknoloji ve } \\
\text { Sosyalleşme }\end{array}$} & Gruplar Aras1 & 2,513 & 3 & 8,838 & \multirow{3}{*}{8,836} & \multirow{3}{*}{, 475} \\
\hline & Gruplar İçi & 267,487 & 267 & 1,002 & & \\
\hline & Toplam & 270,000 & 270 & & & \\
\hline \multirow{3}{*}{ Ortam } & Gruplar Aras1 & 10,450 & 3 & 3,483 & \multirow[t]{3}{*}{3,583} & \multirow[t]{3}{*}{,014* } \\
\hline & Gruplar İçi & 259,550 & 267 & 972 & & \\
\hline & Toplam & 270,000 & 270 & & & \\
\hline \multirow{3}{*}{ İlişkiler } & Gruplar Aras1 & 902 & 3 & 301 & \multirow[t]{3}{*}{298} & \multirow[t]{3}{*}{827} \\
\hline & Gruplar İçi & 269,098 & 267 & 1,008 & & \\
\hline & Toplam & 270,000 & 270 & & & \\
\hline \multirow{3}{*}{ İş Değiştirme } & Gruplar Aras1 & 4,588 & 3 & 1,529 & \multirow[t]{3}{*}{1,538} & \multirow[t]{3}{*}{205} \\
\hline & Gruplar İçi & 265,412 & 267 & ,994 & & \\
\hline & Toplam & 270,000 & 270 & & & \\
\hline
\end{tabular}

Tablo 13'deki test sonuçlarına göre, gelecek beklentisi konusunda iş yerindeki pozisyon bakımdan gruplar arasında sadece ortam $(\mathrm{p}=0,014<0,05)$ boyutu açısından ise fark olduğu \%95 güvenilirlik düzeyinde söylenebilir. Sonuç olarak, katılımcıların gelecek beklentisi konusunda iş yerindeki pozisyon grupları arasında teknoloji ve sosyalleşme, ilişkiler ve iş değiştirme boyutları açısından benzer düşüncelere sahip oldukları görülmüştür.

Gelecek beklentisi konusundaki bu farkın hangi işyerindeki pozisyon grupları arasında olduğunu tespit etmek için aşağıdaki hipotezler tanımlanmıştır.

$\mathbf{H}_{0}$ : Gelecek beklentisi konusundan işyerindeki pozisyon $j$ grubu ile işyerindeki pozisyon $k$ grubu arasında ortam boyutu bakımından fark yoktur.

$\mathbf{H}_{\mathrm{A}}$ : Gelecek beklentisi konusundan işyerindeki pozisyon $j$ grubu ile işyerindeki pozisyon $k$ grubu arasinda ortam boyutu bakımından fark vardır.

Buradaki, $j$ ve $k(j \neq k)$ değişkenleri yarı zamanll, tam zamanll, orta kademe yönetici ve üst düzey yönetici olarak ayrı ayrı tanımlanmıştır. Hipotezleri ise $\% 95$ güvenilirlik düzeyinde Scheffe testi ile çoklu karşılaştırmalar yapılmıştır. Tablo 14 'te çoklu karşılaştırma test sonuçları verilmiştir.

Tablo 14. Scheffe Testi Sonuclar - Gelecek Beklentisi

\begin{tabular}{cccccc}
\hline \multirow{2}{*}{ Değişken } & $\begin{array}{c}\text { (j) Issyerindeki } \\
\text { Pozisyon }\end{array}$ & \multicolumn{1}{c}{$\begin{array}{c}\text { (k) İsyerindeki } \\
\text { Pozisyon }\end{array}$} & $\begin{array}{c}\text { Ortalama Fark1 } \\
(j-k)\end{array}$ & $\begin{array}{c}\text { Standart } \\
\text { Hata }\end{array}$ & $p$ \\
\hline \multirow{2}{*}{ Ortam } & Tam Zamanlı & Yarı Zamanll &, 893 &, 281 &, $009^{*}$ \\
\cline { 2 - 7 } & Orta Kademe Yönetici & Yarı Zamanlı &, 881 &, 329 &, $039^{*}$ \\
\cline { 2 - 7 } & Üst Kademe Yönetici & Yarı Zamanlı & 1,050 &, 368 &, $024^{*}$ \\
\hline
\end{tabular}

*\%95 güvenilirlik düzeyinde anlamlıdır.

Tablo 14'teki test sonuçlarına göre, Y kuşağındaki tam zamanlı çalışan, orta ve üst kademe yöneticilerin ortam ile ilgili gelecek beklentisi yarı zamanlı kişilerden daha olumludur.

Kariyer alg1s1 yaş, işyerindeki pozisyon, işyerindeki çalışma süresi ve toplam iş tecrübesi bakımından katılımc1 grupları arasında her bir boyutun puan ortalamaları arasından fark olmadığı \%95 güvenilirlik düzeyinde varyans analizi (tek yönlü ANOVA) ile tespit edilmiştir. Aynı zamanda gelecek beklentisi için de yaş, işyerindeki çalışma süresi ve toplam iş tecrübesi bakımından katılımcı grupları arasında her bir boyut puan ortalamaları arasından fark bulunmamaktadır. Makalede yer tasarrufu sağlamak için varyans analiz sonuç tablolarına yer verilmemiştir. Talep edildiği durumda test sonuçları sorumlu yazar tarafindan gönderilecektir.

\section{Tartışma, Sonuç ve Öneriler}

Bu araştırma ile Kocaeli Organize Sanayi Bölgesinde çalışan ve aynı zamanda Y kuşağında yer alan katılımcıların kariyer algisının ve gelecek beklentilerinin farkında olunması ve sistemlerin de buna göre iyileştirilmesi amacı doğrultusunda 271 kişiden elde edilen veriler değerlendirilmiş ve aşağıdaki bulgulara ulaşılmıştır: 
(1) $\mathrm{Bu}$ araştırmadaki kariyer algısı ölçeği 3 boyut (motivasyon, uyum ve plan) olarak ortaya çıkmış olup, ölçek güvenilirliği $(\alpha=0,947)$ oldukça yüksek bulunmuştur.

(2) Bu araştırmadaki gelecek beklentisi ölçeği 4 boyut (teknoloji ve sosyalleşme, ortam, ilişkiler ve iş değiştirme) olarak ortaya çıkmıs olup, ölçek güvenilirliği $(\alpha=0,945)$ oldukça yüksek bulunmuştur.

(3) Y kuşağı genel olarak kariyer planlarında kendilerini başarılı olarak görmektedir (Bknz. Tablo 5; \%45,8). Y kuşağ1 bireylerinin kendilerine özgüvenleri yüksektir. İşi beğenmediklerinde veya o işte istedikleri başarıya ulaşamadıklarında iş değiştirme eğiliminde olmaktadır. Bu nedenle istedikleri ve başarılı olabilecekleri işleri tercih ederler. Bu durum kariyer planlarını bilinçli olarak hazırlamalarını sağlamaktadır (Mert, 2018: 713; Mengi, 2011).

(4) Y kuşağı genel olarak çalıştıkları işyerlerinde teknolojinin yeterli olduğunu belirtmektedir (Bknz. Tablo 6; \%43,2). Y kuşağ için teknolojiye erişim çok önemlidir. Teknolojiyi hem iletişim aracı hem de bilgiye erişim amaçlı kullanmaktadır. Bu nedenle çalıştıkları kurumlarda, gereken teknolojik imkanların sunulması konusuna önem vermektedirler. Y kuşağının bu özelliğini literatürde birçok araştırmac1 çalışmalarında (Mert, 2018; Mengi, 2011; Anantatmula ve Shrivastav, 2012; Rettie, 2002; Feirtag ve Berge, 2008; Keleş, 2011; Glass, 2007; Meier ve Crocker, 2010; Yüksekbilgili, 2013) belirtmiştir.

(5) Y kuşağı bireylerinde motivasyon unsuru cinsiyetlerine göre farklılık göstermektedir. Ancak, uyum ve plan konularındaki kariyer algıları cinsiyetlerine göre farklılaşmamaktadır.

(6) Gelecek beklentisi boyutlarından teknoloji ve sosyalleşme, ortam ve iş değiş̧irme Y kuşağında cinsiyete göre farklılaşmaktadır. Fakat, ilişki unsuru cinsiyete göre farklılık göstermemektedir.

(7) Üniversite mezunu Y kuşağı bireylerinin motivasyon düzeyi lise, yüksek lisans veya doktora mezunu kişilerden daha yüksektir.

(8) Üniversite ve yüksek lisans/doktora mezunu kişilerin uyum düzeyleri ise lise mezunu kişilerden daha yüksektir.

(9) Üniversite mezunu Y kuşağ1 bireylerinin teknoloji ve sosyalleşme düzeyi ve iş değiş̧tirme durumları lise mezunu kişilerden daha yüksektir.

(10) Ortama ilişkin gelecek beklentisi ise lise ve üniversite mezunu kişilerin yüksek lisans/doktora mezunu kişilerden daha yüksek olduğu tespit edilmektedir.

(11) Y kuşağındaki tam zamanlı çalışan, orta ve üst kademe yöneticilerin ortam ile ilgili gelecek beklentisi yarı zamanlı kişilerden daha olumludur.

Sadece Kocaeli Sanayi Bölgesi ile sınırlı olan bu araştırmada ulaşılan sonuçlar, Türkiye'de faaliyet gösteren Y kuşağı bireylerinin geneli için yorumlanamasa da; Y kuşağının kariyer algısı ve gelecek beklentisi konusunda önemli ölçüde fikir verdiği, bu anlamda teorisyenlere ve uygulamacılara katkıda bulunduğu söylenebilir. Çalıssmanın Kocaeli ilinde yapılmasının nedeni ise; bu bölge, imalat ve hizmet sektörleri için Türkiye'de merkezi bir konumdadır. Ayrıca bu bölge, insan kaynağı açısından oldukça fazla çeşitlilik göstermektedir. Bu bölgede çalışan bireylerin çoğunluğunu ise Y kuşağı oluşturmaktadır.

Günümüz işgücü piyasasının büyük bir kısmını teşkil eden Y kuşağının kişilik özellikleri, yaşam tarzları, kariyer algıları, gelecek beklentileri ve daha birçok özellikleri diğer kuşaklara göre derin farklılıklar göstermektedir. Araştırmada elde edilen sonuçlar da bu durumu destekler niteliktedir. Y kuşağı ile çalışmak önceki kuşaklara göre daha zor olsa da örgütler bu kuşağın donanımından ve yeteneklerinden yararlanmak için stratejilerini geliştirmelidirler.

Y kuşağı, yetenekleri tanımlandığında ve kendilerini zorlayan işlerle uyumlaştırıldığında örgüte bağlılıkları ve performansları artmaktadır. Dolayısıyla; örgütler Y kuşağının potansiyelini ortaya çıkarak ve beklentilerini karşılayabilecek liderlik ve kariyer politikalarını geliştirmeli ve uygulamalarını Y kuşağı çalışanını örgütte kalmalarını sağlayacak şekilde değiştirmelidirler.

Y kuşağı üzerine çalışacak araştırmacılar kuşaklar arası farkllıkları inceleyebilir, girişimciliğin Y kuşağında yaygınlaşmasının nedenini araştırabilirler. Benzer konulu araştırmalar, Türkiye genelinde bölgeler arasında Y kuşağının farklılıkları araştırılarak, sonuçlar karşılaştırılabilir. Böylece, tüm Türkiye'deki Y kuşağının kariyer algısı ve gelecek beklentisi, daha iyi şekilde ortaya konabilir. Aynı zamanda, araştırmanın yapılacak çeşitli ölçeklerle geliştirilmesi, faydalı yeni sonuçlar da ortaya çıkarabilecektir. Gelecek çalışmalarda örgütlerin strateji ve politikalarındaki uygulamalarının $\mathrm{Y}$ kuşağı tarafindan benimsenip- 
benimsenmediği, kuşaklar arasında örgütsel bağlılık, örgütsel vatandaşlık ve örgütsel çatışmaların nasıl farklılaştı̆̆ incelenip, farklılıklardaki nedenler sorgulanabilir.

\section{Etik Beyan}

"Y Kuşağının Kariyer Algısı ve Gelecek Beklentisi: Kocaeli Organize Sanayi Bölgesi Örneği” başlıklı çalışmanın yazım sürecinde bilimsel, etik ve alıntı kurallarına uyulmuş; toplanan veriler üzerinde herhangi bir tahrifat yapılmamış ve bu çalışma herhangi başka bir akademik yayın ortamına değerlendirme için gönderilmemiştir.

\section{Kaynakça}

Adıgüzel, O., Batur, H. Z. ve Ekşili, N. (2014). Kuşakların değişen yüzü ve Y kuşağı ile ortaya çıkan yeni çalışma tarzi: Mobil yakallır. Süleyman Demirel Üniversitesi Sosyal Bilimler Enstitisï Dergisi, 19(1), 165-182.

Akdemir, A., Konakay, G., Demirkaya, H., Noyan, A., Demir, B., Ağ, C., Pehlivan, Ç, Özdemir, E., Akduman, G., Eregez, H., Öztürk, İ. ve Balc1, O. (2013). Y kuşağının kariyer algısı, kariyer değisşimi ve liderlik tarzı beklentilerinin araşıırılması. Ekonomi ve Yönetim Araștırmalar Dergisi, 2(2), 11-42.

Akdeniz, E. (2012). Teknoloji çocuklar: Z kusağg. Retrieved from http://www.infopik.com/infografik/teknolojicocuklari-z-kusagi.

Altunışık, R., Coşkun, R., Bayraktaroğlu, S. ve Yıldıım, E. (2005). Sosyal bilimlerde araştırma yöntemleri: SPSS uygulamal. Sakarya: Sakarya Kitabevi.

Altuntuğ, N. (2012). Kuşaktan kuşağa tüketim olgusu ve geleceğin tüketici profili. Organizasyon ve Yönetim Bilimleri Dergisi, 4(1), 203-212.

Aminul, I., Cheong T. W., Yusuf, H. ve Desa, H. (2011). A study on generation at workplace in penang. Journal of Applied Sciences Research, 7(11), 1802-1805.

Anantatmula, V. S. ve Shrivastav, B. (2012). Evolution of project teams for generation Y workforce. International Journal of Managing Projects in Business, 5(1), 9-26.

Arıkan, R. (2004). Arastrma teknikleri ve rapor hazırlama. Ankara: Asil Yayınevi.

Balc1, A. (2001). Sosyal bilimlerde arastrma, yöntem, teknik ve ilkeler. Ankara: Pegem Yayınevi.

Baltaş, A. (2010). Y kuşağını yönetmek. Kaynak Dergisi, 41, 28-31.

Bektaş, H. ve Akman, S. U. (2013). Yükseköğretimde hizmet kalitesi ölçeği: Güvenilirlik ve geçerlilik analizi. İstanbul Üniversitesi İktisat Fakültesi Ekonometri ve İstatistik Dergisi, 18, 116-133.

Broadbridge, A. M., Maxwell, G. A. ve Ogden, S. M. (2007). Experiences, perceptions and expectations of retail employment for generation Y. Career Development International, 12(6), 523-544.

Chester, E. (2002). Employing generation why? Lakewood: Tucker House Books.

Coggshall, E. ve Coggshall, J. G. (2010). Realizing the promise of generation Y: The key to changing the teaching profession. Retrieved from https://pamsinstructionaltraining.wikispaces.com/file/view/Education+Leadership+Article.pdf.

Coupland, D. (1989). Generation X: Tales for an accelerated culture. New York: St. Martin's Press.

Cronbach, L. J. (I990). Essentials of psychological testing (5 $5^{\text {th }}$ Edition). New York: Harper Collins.

Çoban, F. (2006). Milenyum kuşağı neleri değiştirecek? Capital Dergisi, Retrieved from http://proje.capital.com.tr/milenyum-kusagi-neleri-degistirecekhaberler/18974.aspx.

Çokluk, Ö., Şekercioğlu, G. ve Büyüköztürk, Ş. (2012). Sosyal bilimler için çok değgiskenli istatistik: SPSS ve LiSREL uygulamalar. Ankara: Pegem Akademi Yayincilik.

Dede, Y. ve Yaman, S. (2008). Fen öğrenmeye yönelik motivasyon ölçeği: geçerlik ve güvenirlik çalışması. Necatibey Eğitim Fakültesi Elektronik Fen ve Matematik Eğitimi Dergisi (EFMED), 2(1), 19-37.

Demirkaya, H., Akdemir, A., Karaman, E. ve Atan, Ö. (2015). Kuşakların yönetim politikası beklentilerinin araştırılması. İsletme Araștrmalar Türk Dergisi, 7(1), 186-204.

Durmuş, B., Çinko, M. ve Yurtkoru, E. S. (2016). Sosyal bilimlerde SPSS'le veri analizi (6. Baskı). İstanbul: Beta Yayincilik.

Ercan, M. (2012). Dijital çăg ve C kuşăğ. Retrieved from http://www.radikal.com.tr/yazarlar/metin_ercan/dijital_cag_ve_c_kusagi-1079843.

Feirtag, J. ve Berge, Z. L. (2008). Training generation N: How educators should approach the net generation. Education + Training, 50(6), 457-464.

Gioncola, F. (2006). The generation gap: More myth than reality? Human Resource Planning, 29(4), 32-37.

Glass, A. (2007). Understanding generational differences for competitive success. Industrial and Commercial Training, 39, 98-103.

Gusfield, J. R. (1957). The problem of generations in an organizational structure. Social Forces, 35(4), 323-330.

Hardey, M. (2011). Generation C: Content, creation, connections and choice. International Journal of Market Research, $53(6), 749-770$

İçil, M. (2016). Dijital dünyanın yarattığı C jenerasyonu. Retrieved from www.mustafaicil.com/blog/dijital-dunyaninyarattigi-c-jenerasyonu. 
Joshi, A., Dencker, J. C. ve Franz, G. (2011). Generations in organizations. Research in Organizational Behavior, 31, $177-$ 205.

Keleş, H. N. (2011). Y kuşağı çalışanlarının motivasyon profillerinin belirlenmesine yönelik bir araştırma. Bahçeşehir Üniversitesi Organizasyon ve Yönetim Bilimleri Dergisi, 3(2), 129-139.

Kılıç, M. S. (2012). XYZ Kuşă̆ı. Retrieved from http://yenisafak.com.tr/pazar-haber/kanaatkar-talepkar-sabirsiz16.12.2012-436173.

Kupperschmidt, B. (2000). Multi generation employees: Strategies for effective management. The Health Care Manager, 19(1), 65-76.

Macky, K., Gardner, D. ve Forsthy, S. (2008). Generational differences at work: Introduction and overview. Journal of Managerial Psychology, 23(8), 857-861.

Martin, A. C. ve Tulgan, B. (2002). Managing the generation mix: from collision to collaboration. Massachusetts: HRD Press.

Meier, J. ve Crocker, M. (2010). Generation Y in the workforce: Managerial challenges. The Journal of Human Resource Adult Learning, 6(1), 68-78.

Mengi, Z. (2011). Iss başarisında kuşak. farkı. Retrieved from http:/ / www.optimist.com.tr.

Mengi, Z. (2012). Z kuşăğ geliyor. Retrieved from http://www.zeynepmengi.com/2012/06/z-kusagi-geliyor/.

Mert, G. (2018). Y kuşağı açısından yönetim (1. Baskı). İstanbul: Beta Basım.

O'Bannon, G. (2001). Managing our future: The generation X factor. Public Personnel Management, $30,95$.

Özdemir, G., Gökdağ, R. ve Neslihanoğlu, S. (2019). Sosyal medyada emoji kullanımı ve anlamlandırılması: Anadolu üniversitesi iletişim fakültesi örneği. Selçuk Üniversitesi İletişim Fakültesi Akademik Dergisi, 12 (1), 425-443.

Patır, S. (2009). Faktör analizi ile öğretim üyesi değerleme çalışması. Atatürk Üniversitesi İktisadi ve İdari Bilimler Dergisi, 23(4), 69-85.

Punch, K. (2005). Introduction to social research - quantitative and qualitative approach (2. Edition). California: Sage Publications Inc.

RANDSTAD. Research Reports. Retrieved from http://www.randstad.com/press-room/researchreports.

Reeves, T. C. ve Oh, E. (2008). Generational differences in handbook of research on educational communications and technology (3th Edition). New York: Taylor \& Francis Group.

Rettie, R. (2002). Net generation culture. Journal of Electronic Commerce Research, 3(4), 254-264.

Senbir, H. (2004). Z son insan mı? Z kuşă̆ı ve sonrasina dair düşünceler (2. Baskı). İstanbul: Okuyan Us Yayınevi.

Sheahan, P. (2006). Generation $Y$ and surviving: Thriving with generation y at work. Australia: Hardie Grant Books.

Smith, T. W. (2000). Changes in the generation gap 1972-1998. GSS Social Change Report, Chicago: National Poinion Research Center, University of Chicago.

Smola, K. W. ve Sutton, C. D. (2002). Generational differences: Revisiting generational work values for the new millennium. Journal of Organizational Behavior, 23(4), 363-382.

Twenge, J. M. (2010). A review of the empirical evidence on generational differences in work attitudes. Journal of Business Psychology, 25, 201-210.

Yelkikalan, N., Akatay, A. ve Altın, E. (2010). Yeni girişimcilik modeli ve yeni nesil girișimci profili: İnternet girişimciliği ve Y, M, Z kuşaği girişimci. SÜ İIBF Sosyal ve Ekonomike Araştırmalar Dergisi, 10(20), 489-506.

Yüksekbilgili, Z. (2013). Türk tipi Y kuşağı. Elektronik Sosyal Bilimler Dergisi, 12(45), 342-353.

Zemke, R., Raines, C. ve Filipczak, B. (2013). Generations at work: Managing the clash of boomers, Gen Xers, and Gen Yers in the Workplace (2. Edition). USA: Amacom.

\section{EXTENDED ABSTRACT}

$\mathrm{Y}$ generation is a generation consisting of individuals born in between 1980-2000. This generation is called also "internet generation", "Millennial", "Echo-Boomers" and "Nexters". These definitions are used for indicating the difference of $\mathrm{Y}$ generation with earlier generations.

The behavior and expectance of $Y$ generation at work shows variance from other generations. They are extremely fond of freedom. They cannot give up technology and they want to implement technology in their work. This generation gives importance to socialness and they do not let business life to surpass this. Y generation has a high career expectation. They learn fast and show quick improvement. The wish to become manager is short time. Major responsibilities have been given to $\mathrm{Y}$ generation managers. When their expectations are not met, $\mathrm{Y}$ generation quickly decides to change jobs. If $\mathrm{Y}$ generation is not managed well, this affects the organization negatively. Y generation should be managed via personalization and specialization. Coaching and mentoring are important for $\mathrm{Y}$ generation. $\mathrm{Y}$ generation which is in a more competitive life, prefer finance, consultancy and informatics fields, search for jobs in electronic media, gives importance for the place they shall work for to be international, to have an identity and career and training opportunities.

The expectations of $Y$ generation show differences compared to other generations. Y generation sees to look for a new job when the job it performs does not meet the expectations in life as not selfishness but realism. Y generation individuals, as they are raised with patents and teachers that support them to be successful in all their activities, when they are giving decisions related to their future, they need to consult 
their patents or to role models with more experience and knowledge whom they trust. Also, to see that their activities contribute to a positive change in the world is very important for them. Y generation represents a generation with more positive expectations for the future, that produces innovative ideas, contribute to the processes or activities and wish that these are recognized.

The research is performed for awareness of the career perception and expectations of the future of the participants who work in Kocaeli Organized Industrial Zone and at the same time belong to the Y generation and improving their systems accordingly in between October- November 2018. In the research data of 271 participants is examined. Participants are $64.2 \%$ male and $35.8 \%$ female. $15.5 \%$ of the participants are in $18-22$ years age group, $31.4 \%$ in $23-27$ years, $33.2 \%$ in $28-32$ years, $19.9 \%$ in $33-37$ years age group. It is observed that $38.4 \%$ of the participants are high school graduates, $43.2 \%$ are university graduate and $18.4 \%$ are masters/doctorate degree graduate. When the workplace positions of the participants are considered, they are composed of $4.8 \%$ part-time employees, $78.6 \%$ full-time employees, $10.7 \%$ junior managers and $5.9 \%$ senior manager. When the working periods at the workplaces of the participants is examined, it is seen that the ones have been working for less than 1 year are $18.1 \%$, between 1 to 3 years are $78.2 \%$, and between 4 to 6 years are 3.7\%. Among the participants, the ones with work experience less than 1 year are $19.6 \%$, between 1 to 3 years are $9.2 \%, 4$ to 6 years $21.4 \%$, between 7 to 9 years are $20.3 \%$ and more than 10 years is $29.5 \%$.

The "career perception" and "future expectations" scales used in the research is developed by the researchers for the first time and the literature on the subject is taken as basis. For the career perception 19 and for the future expectations 19 scale statements are prepared. The scales are classified within 5point likert scale with statements "completely disagree", "disagree", "undecided", "agree", and "completely agree".

In the study for the participant, the career perception's $(\mathrm{KMO}=0.932)$ determination is reduced to motivation, harmony and plan dimensions with factor analysis and their thoughts on future expectations $(\mathrm{KMO}=0.944)$ is reduced by the same method with factor analysis to technology and socializing, environment, relations and job changing dimensions. The reliability of the scales is measured by the Cronbach's Alpha coefficient. In the analyses conducted the scales are determined to have high level internal consistency $\left(\alpha_{\text {Career Perception }}=0.947 ; \alpha_{\text {Future Expectations }}=0.945\right)$.

Whether there is a difference regarding the dimensions defined regarding gender, age, education status, position at workplace, working hours at the workplace and total work experience, respectively, related to the career perception and future expectations of the participants are examined by hypotheses. For this purpose, Independent Groups t Test, One Way ANOVA, Scheffe Tests are applied.

When the results of the research are examined, motivation element in Y generation individuals shows difference according to gender. However, it is determined that their career perception in harmony and plan subjects do not vary according to their gender.

Among the future expectations' dimensions, technology and socializing, environment and job changing varies according to gender in $\mathrm{Y}$ generation. However, relationship element does not vary according to gender. University graduate $\mathrm{Y}$ generation individuals' motivation level is higher than high school, masters or doctorate graduate individuals. The harmony level of university and masters/doctorate graduate individuals is higher than the high school graduate individuals. The technology and socializing level and job changing conditions of university graduate $\mathrm{Y}$ generation individuals are higher than high school graduate individuals. The future expectation regarding the environment is detected that it is higher in high school and university graduate individuals than masters/doctorate graduate individuals. The future expectations of fulltime employees, junior and senior manager in $\mathrm{Y}$ generation regarding the environment is more positive than part-time employee individuals.

In this research limited with only the Kocaeli Industrial Zone, the results acquired, while cannot be interpreted for the generality of the $\mathrm{Y}$ generation individuals active in Turkey, can be said to give substantial ideas in career perception and future expectations of the $\mathrm{Y}$ generation, and this regard provides contribution for the theoreticians and practitioners. 